Boston University School of Law

Scholarly Commons at Boston University School of Law

Faculty Scholarship

$11-2020$

\title{
In Defense of Breakups: Administering a "Radical” Remedy
}

Rory Van Loo

Boston University School of Law

Follow this and additional works at: https://scholarship.law.bu.edu/faculty_scholarship

Part of the Antitrust and Trade Regulation Commons, and the Business Organizations Law Commons

\section{Recommended Citation}

Rory Van Loo, In Defense of Breakups: Administering a "Radical" Remedy, in 105 Cornell Law Review 1955 (2020).

Available at: https://scholarship.law.bu.edu/faculty_scholarship/954

This Article is brought to you for free and open access by Scholarly Commons at Boston University School of Law. It has been accepted for inclusion in Faculty Scholarship by an authorized administrator of Scholarly Commons at Boston University School of Law. For more information, please contact lawlessa@bu.edu. 


\section{HEINONLINE}

DATE DOWNLOADED: Wed Oct 19 23:17:16 2022

SOURCE: Content Downloaded from HeinOnline

Citations:

Bluebook 21st ed.

Rory Van Loo, In Defense of Breakups: Administering a "Radical" Remedy, 105 CORNELL

L. REV. 1955 (2020).

ALWD 7th ed.

Rory Van Loo, In Defense of Breakups: Administering a "Radical" Remedy, 105 Cornell

L. Rev. 1955 (2020).

APA 7th ed.

Van Loo, R. (2020). In defense of breakups: administering "radical" remedy. Cornell

Law Review, 105(7), 1955-2022.

Chicago 17th ed.

Rory Van Loo, "In Defense of Breakups: Administering a "Radical" Remedy," Cornell Law Review 105, no. 7 (November 2020): 1955-2022

McGill Guide 9th ed.

Rory Van Loo, "In Defense of Breakups: Administering a "Radical" Remedy" (2020) 105:7

Cornell L Rev 1955.

AGLC 4th ed.

Rory Van Loo, 'In Defense of Breakups: Administering a "Radical" Remedy' (2020)

105(7) Cornell Law Review 1955

MLA 9th ed.

Van Loo, Rory. "In Defense of Breakups: Administering a "Radical" Remedy." Cornell

Law Review, vol. 105, no. 7, November 2020, pp. 1955-2022. HeinOnline.

OSCOLA 4th ed.

Rory Van Loo, 'In Defense of Breakups: Administering a "Radical" Remedy' (2020) 105

Cornell L Rev 1955

Provided by:

Fineman \& Pappas Law Libraries

-- Your use of this HeinOnline PDF indicates your acceptance of HeinOnline's Terms and Conditions of the license agreement available at

https://heinonline.org/HOL/License

-- The search text of this PDF is generated from uncorrected OCR text.

-- To obtain permission to use this article beyond the scope of your license, please use: Copyright Information 


\title{
IN DEFENSE OF BREAKUPS: ADMINISTERING A "RADICAL" REMEDY
}

\author{
Rory Van Loo $\dagger$
}

Calls for breaking up monopolies-especially Amazon, Facebook, and Google-have largely focused on proving that companies like Whole Foods, Instagram, and YouTube are anticompetitive. But scholars have paid insufficient attention to a separate step in the analysis that may help explain why the government in recent decades has not broken up a single large company. After establishing that an anticompetitive merger or other act has occurred, there is great skepticism of breakups as a remedy. Judges, scholars, and regulators see a breakup as extreme, frequently comparing the remedy to trying to "unscramble eggs." They doubt the government's competence in executing such a difficult task, pointing to decision-making flaws dating back to the breakups of Standard Oil in 1911 and AT\&T in 1984. Even scholars calling for more vigorous antitrust enforcement often recommend alternative remedies.

This Article asserts that the pervasive hesitancy about administering breakups renders antitrust impotent in the face of monopolies - too often a statutory right without a remedy. More importantly, the Article challenges the perception of breakups as unadministrable. The intellectual foundations for the anti-breakup stance are weak, relying on outdated, anecdotal evidence. Moreover, antitrust needs a methodological shift toward paying greater attention to the breakup insights yielded by other disciplines. In particular, business scholars have studied how the world's leading companies regularly break themselves up voluntarily. Additionally, administrative law scholarship has observed a broader evolution toward collaborative regulation that shows how the much-maligned historical approaches to antitrust remedies could be greatly improved by relying more on the business sector in designing and implementing breakups. In other words, insights from

+ Associate Professor of Law, Boston University; Affiliated Fellow, Yale Law School Information Society Project. For valuable input, I am grateful to Rebecca Haw Allensworth, John Newman, Menesh Patel, Georgios Petropoulos, Danny Sokol, Ashwin Vasan, David Walker, and Ramsi Woodcock. Brianne Allan, Samuel Burgess, Leah Dowd, Derek Farquhar, Brian Flaherty, Shecharya Flatte, Ian Horton, Ryan Kramer, Jack Langa, Tyler Stites, and Brittany Swift provided excellent research assistance. 
outside of antitrust address many critiques of breakups and show how the remedy is far from radical and messy.

Antitrust observers should thus abandon the worldview that compares breaking up prior companies to unscrambling eggs. Or, at a minimum, they should recognize that scrambled eggs, once cooked, are divided into smaller portions. A greater willingness to do the same to monopolies in the post-merger context and beyond would bring regulators more in line with the business sector, which sees divestitures as a routine part of effective governance.

INTRODUCTION ........................... 1956

I. THE ANTITRUST REMEDY CONUNDRUM ............ 1961

A. Breakups as the Favored Remedy

Administering Breakups ............... 1961

II. THE WEAK EVIDENCE AGAINST ADMINISTRABILITY . . . . 1972

A. The Limitation of Case Studies... . . . . . . . . 1972

B. The Lack of Systemic Evidence .......... 1976

III. A BALANCED VIEW OF BREAKUPS .............. 1981

A. Insights from Private Divestitures ......... 1981

1. Are Private Divestitures Too Different To Be Helpful? ........................ 1982

2. What Insights Might Private Divestitures Offer? ......................... 1985

B. Shareholder Harm Is Not an Obstacle ....... 1990

C. Costly Breakups May Increase Deterrence.... 1995

IV. IMPLICATIONS . . . . . . . . . . . . . . . . . . . . . . . . 1998

A. Administering Breakups .............. 1998

B. Choosing Breakups................. 2006

1. Comparing Breakups to Access Remedies . 2006

2. Comparing Breakups to Inaction and Other

Alternatives..................... 2012

C. Expanding Breakups ................. 2014

CONCLUSION .............................. 2020

\section{INTRODUCTION}

In the wake of bipartisan momentum to prosecute big tech companies, antitrust authorities have acknowledged that breakups are "perfectly on the table." 1 But this remedy faces intellectual opposition from a broader range of the ideological spectrum than many realize. Academics have driven a renais-

1 Rob Copeland, Breakup of Tech Giants 'on the Table,' U.S. Antitrust Chief Says, WALl STREET J. (Oct. 22, 2019, 2:00 PM), https://www.wsj.com/articles/ breakup-of-tech-giants-on-the-table-u-s-antitrustchief-says-1 1571765689 [https://perma.cc/9NXG-SXM2] (quoting Makan Delrahim, head of the DOJ Antitrust Division). 
sance in antitrust scholarship, calling for stronger remedies for anticompetitive behavior, with some proposing breakups. ${ }^{2}$ The breakup attention has focused on whether large corporations are violating antitrust laws and how a given breakup would alter competition once the process is complete. ${ }^{3}$ Yet to pursue breakups, policymakers must also believe that authorities can administer them, and that the remedy is reasonable. Otherwise, courts would insist on another solution, such as mandating that tech companies provide competitors with access to their platforms. ${ }^{4}$ In the wake of intensifying scholarly serutiny of antitrust, there has been no sustained attention to administering breakups. 5

In the absence of close examination, the dominant view has remained that breakups are "radical" 6 and too costly-even among influential scholars supportive of more vigorous antitrust enforcement. ${ }^{7}$ The biggest conceptual barrier is the belief that breakups are too difficult for the government to administer. ${ }^{8}$ As judges, scholars, and regulators have repeatedly put

2 Scholars have for decades called for reforming antitrust, in what can be described as the Post-Chicago antitrust movement. See generally HOW THE CHICAGO SCHOOL OVERSHOT THE MARK: THE EFFECT OF CONSERVATIVE ECONOMIC ANALYSIS ON U.S. ANTITRUST (Robert Pitofsky ed., 2008) (sharing scholarship by Jonathan Baker, Eleanor Fox, Herbert Hovenkamp, Marina Lao, John Kirkwood, Daniel Rubinfeld, and Steven Salop, among others). Members of that group and the more recent "Neo-Brandeisian" antitrust movement have called for expanding breakups. See Tim Wu, THE CuRSE OF BIGNESS: ANTTRUST IN THE NEW GILDED AGE 132-33 (2018); Steven C. Salop, Invigorating Vertical Merger Enforcement, 127 YALE L.J. 1962, 1982 (2018); Lina M. Khan, Note, Amazon's Antitrust Paradox, 126 YALE L.J. 710, 800 (2017).

3 See supra note 2.

4 See infra subparts I.B \& IV.B.2.

5 See infra Part I (summarizing the literature).

6 See, e.g., United States v. Microsoft Corp., 253 F.3d 34, 80 (D.C. Cir. 2001) ("WW]isdom counsels against adopting radical structural relief."); Todd Spangler, Will the U.S. Break Up Big Tech? Don't Hold Your Breath, VARIETY (June 4, 2019, 1:36 PM), https://variety.com/2019/digital/news/us-antitrust-break-upfacebook-google-amazon-apple-1203232588/ [https://perma.cc/2S6N-7NSS] (quoting Professor Herbert Hovenkamp as saying "[b]reakup remedies are radical and they frequently have unintended consequences").

7 See Herbert Hovenkamp, Progressive Antitrust, 2018 U. ILL. L. REv. 71, 99; Fiona Scott Morton, Why 'Breaking Up' Big Tech Probably Won't Work, WASH. POST (July 16, 2019, 2:41 PM), https://www.washingtonpost.com/opinions/2019/07/ 16/break-up-facebook-there-are-smarter-ways-rein-big-tech/ [https:// perma.cc/TE4W-N2F6] ("Just 'break them up' is an oversimplified sound bite, not a real policy that would restore competition in digital markets and benefit consumers.").

8 See Hovenkamp, supra note 7, ("The main reason antitrust does not go further is concerns about administrability."); see also Menesh S. Patel, Merger Breakups, 2020 WIS. L. REV. 975 (manuscript at 42, 50-51) (on file with the Cornell Law Review), https://papers.ssrn.com/sol3/papers.cfm?abstract_id=3469984 (concluding that more ex post merger reviews are 
it, breaking up a merged company is like trying to "unscramble the eggs." 9

That administrative resistance to breakups is overlooked in conversations about reforming antitrust, but it poses an existential problem. In theory, to combat monopoly power obtained through an illegal merger, authorities have long preferred breaking up the company to the "perilous" alternative-behavioral remedies, which require ongoing government oversight of the monopolist. ${ }^{10}$ Yet if the preferred remedybreakups-has become so infeasible that "we may as well forget about attempting to disestablish" integrated firms, ${ }^{11}$ the law may offer no acceptable remedy to address illegal monopolies.

Through an outside-of-antitrust lens, this Article challenges the prevailing assumption that breakups are extreme and prohibitively difficult to administer. It contributes the first review of the empirical evidence on the administration of breakups, showing that the studies largely responsible for the early view of breakup administration as "clearly a disaster" 12 suffer from flawed methodologies. ${ }^{13}$ Moreover, scholars' frequent critiques of breakups from decades ago, and sometimes more than a century ago in the case of Standard Oil, have limited relevance. ${ }^{14}$ Part of the problem is that large antitrust break-

necessary, but cautioning against breakups when entities have integrated their assets because of "the fundamental difficulties of unwinding consummated mergers").

9 See, e.g., Consol. Gold Fields PLC v. Minorco, S.A., 871 F.2d 252, 261 (2d Cir. 1989) ("[O]nce the tender offer has been consummated it becomes difficult, and sometimes virtually impossible, for a court to 'unscramble the eggs.' " (quoting Sonesta Int'l Hotels Corp. v. Wellington Assocs., 483 F.2d 247, 250 (2d Cir. 1973))); see also Laidlaw Acquisition Corp. v. Mayflower Grp., Inc., 636 F. Supp. 1513, 1517 (S.D. Ind. 1986) (referring to the "virtual impossibility of 'unscrambling the scrambled eggs'"); William J. Baer, Reflections on Twenty Years of Merger Enforcement Under the Hart-Scott-Rodino Act, 65 ANTITRUST L.J. 825, 830 (1997) ("Once a merger takes place and the firms' operations are integrated, it can be very difficult, or impossible, to unscramble the eggs and reconstruct a viable, divestable group of assets."); F. David Osinski, Merger Remedies and the Undersupply of Economic Research, 18 ABA ANTTRUUST L. SEC. ECON. COMMTTEE NEWSL. 5, 7 (2017) ("[I]n consummated mergers, . . . a divestiture may not restore competition due to the high cost and risk of unscrambling the eggs.").

10 Philip J. Weiser, Reexaminting the Legacy of Dual Regulation: Reforming Dual Merger Review by the DOJ and the FCC, 61 FED. COMM. L.J. 167, 176 (2008).

11 Frank H. Easterbrook \& Daniel R. Fischel, Antitrust Suits by Targets of Tender Offers, 80 Mich. L. REv. 1155, 1163 (1982).

12 Barbara A. Clark, Merger Investigations at the Federal Trade Commission: An Insider's Vlew, 56 ANTITRUST L.J. 765, 774-75 (1987).

13 See infra subpart II.B.

14 See infra subpart II.A (explaining limitations in leading historical case studies). 
ups have not occurred in decades, and were always rare, leaving an absence of recent data points.

Rather than relying on outdated and discredited antitrust research, this Article situates breakups within their current business and administrative contexts. Antitrust debates fail to consider the insights generated by routine private sector breakups. One-third of mergers and acquisitions (M\&A)-more appropriately termed reorganizations-are divestitures. ${ }^{15}$ These divestitures include some of the largest deals of the last decade, including Fox's sale of its 20th Century Fox production arm for $\$ 71$ billion to Disney, eBay's spinoff of PayPal, and HewlettPackard's decision to split itself down the middle to create two of the one hundred largest U.S. companies. ${ }^{16}$ Despite meaningful differences, the prevalence of these deals alone is informative because what antitrust observers have come to view as drastic is commonplace in the business world.

Moreover, scholars in other fields-notably strategic management, finance, and organizational behavior-have studied voluntary private sector breakups extensively. ${ }^{17}$ They have shown how these voluntary divestitures add value and how better process design can improve their implementation. ${ }^{18}$ Of course, it is important to recognize that even if antitrust breakups are costly and lower the firm's value, they may be economically beneficial by deterring executives from pursuing anticompetitive deals. ${ }^{19}$ But by remaining disconnected from the extensive business scholarship on divestitures, the antitrust literature has exaggerated breakups' costs and governmental incompetence in administering them.

15 Matthias F. Brauer \& Margarethe F. Wiersema, Industry Divestiture Waves: How a Firm's Position Influences Investor Returns, 55 ACAD. MGMT. J. 1472, 1472 (2012).

16 See Peter Lee, Reconceptualizing the Role of Intellectual Property Rights in Shaping Industry Structure, 72 VAND. L. REV. 1197, 1243 n.315 (2019); Anjanette H. Raymond \& Abbey Stemler, Trusting Strangers: Dispute Resolution in the Crowd, 16 CARDOZo J. Conflict Resol. 357, 379-80 (2015); Shira Ovide, Joann S. Lublin \& Dana Mattioli, Hewlett-Packard Set to Break Up 75-Year-Old Company, WALL STREET J. (Oct. 6, 2014, 9:08 PM), https://www.wsj.com/articles/hewlettpackard-to-split-into-two-companies-1412592132 [https://perma.cc/9MPZN6TD]; Fortune 500, FORTUNE, https://fortune.com/fortune500 [https:// perma.cc/4CLP-GXZ6) (last visited Dec. 26, 2019).

17 See Caterina Moschieri \& Johanna Mair, Research on Corporate Divestitures: A Synthesis, 14 J. MGMT. \& ORG. 399, 400 (2008) (“[O]nly by integrating literature in finance, strategy and organizational behavior can we obtain a comprehensive picture of divesting modes, antecedents, mechanisms and outcomes .....”.

18 See infra subpart III.A (reviewing the literature).

19 See infra Part III (covering deterrence and shareholder harm). 
Regulatory scholarship can also improve the antitrust conceptualization of breakups. Antitrust scholars focus far more on ex post enforcement actions and legal cases, whereas scholars in environmental law and other regulatory fields extensively analyze the monitoring of firms and design of regulatory processes. ${ }^{20}$ In particular, the literature in those other fields is in dialogue with a prominent strand of research, associated with administrative law, arguing for collaborative governance. ${ }^{21}$

Approaching breakup administration less as an adversarial law enforcement procedure and more as collaborative governance could streamline the process, which would speak to one of the biggest critiques of breakups: delay. Also, collaborative governance aims to leverage business sector expertise to compensate for administrative agency sophistication shortfalls and information asymmetries. Most concretely, this would mean not only leveraging the monopoly's resources, but also involving independent third-party M\&A consultants. Thus, by drawing on the collaborative governance literature it becomes possible to see beyond the limitations that breakups faced decades ago and adopt a more realistic assessment of how they would work today.

The implications of a more informed view of breakup administrability are far-reaching. A misguided view of breakups may help explain what many observers see as decades of weak antitrust enforcement, leading to charges that "the deck is stacked in favor of large powerful firms."22 Executives know that if they execute an anticompetitive merger by quickly integrating the companies, antitrust enforcers or courts will fear breaking up the resulting company. ${ }^{23}$ Ironically, unfounded fears of doing harm through breakups may lead to either harmful inaction or weaker remedies that are more likely to prove wasteful. If widespread and unfounded resistance to adminis-

20 This disconnect reflects the institutional design of different agencies. See Rory Van Loo, Regulatory Monitors: Policing Firms in the Compliance Era, 119 COLUM. L. REv. 369, 436-40 (2019).

21 See, e.g., IAN Ayres \& JOHN BRATthwarte, RESPONSIVE REgulation: TRANSCENDING THE DEREGULATION DEBATE 4-7 (1992) loffering a model of responsive regulation); Jody Freeman, Collaborative Governance in the Administrative State, 45 UCLA L. REV. 1, 4 (1997) ('I propose a normative model of collaborative governance that seeks to respond to complaints about the failings of contemporary regulation.").

22 Carl Shapiro, Antitrust in a Time of Populism, 61 INT'L J. INDUS. ORG. 714, 745 (2018).

23 See infra subpart III.C. 
tering breakups has contributed substantially to the presence of monopolies, it has imposed considerable costs on society. ${ }^{24}$

Once breakups are understood as a normal part of business affairs, and as capable of being co-administered with the private sector, courts and enforcers can deploy them more readily as an antitrust remedy. That shift helps to solve the antitrust problem of what to do after an anticompetitive merger has occurred. But it also informs debates about how to handle monopolies that achieved their dominance in other ways. ${ }^{25}$ At the very least, the intuitive resistance to breakups needs to end. Unless and until greater evidence is produced that breakups harm society, judges should be less hesitant to approve breakups, enforcers less tentative to pursue them, and policymakers less resistant to write laws that deploy them.

\section{I}

\section{THE ANTITRUST REMEDY CONUNDRUM}

Breakups exist in a state of conceptual tension. They are often described as the preferred antitrust remedy, yet they are persistently avoided in practice. This Part outlines the underappreciated hostility to administering breakups.

\section{A. Breakups as the Favored Remedy}

Antitrust remedies can be classified as behavioral or structural. Behavioral remedies-sometimes called conduct remedies-seek to make the monopolist take or stop taking some action, such as providing product access to rivals or prohibiting restrictive contract clauses. ${ }^{26}$ In contrast, breakups are a structural remedy in which a company typically transfers assets-such as by selling a business unit or intellectual property to another company-or splits itself into two or more pieces. ${ }^{27}$

24 This is true whether one believes that the goal of antitrust law should be to advance consumer welfare or something larger, such as reducing inequality. On distribution and antitrust, see Jonathan B. Baker \& Steven C. Salop, Antitrust, Competition Policy, and Inequality, 104 GEo. L.J. ONLINE 1, 11 (2015); Lina Khan \& Sandeep Vaheesan, Market Power and Inequality: The Antitrust Counterrevolution and Its Discontents, 11 HARV. L. \& POL'Y REV. 235, 236-37 (2017); Rory Van Loo, Broadening Consumer Law: Competition, Protection, and Distribution, 95 NOTRE DAME L. REV. 21 1, 213, 216 (2019). But see Daniel A. Crane, Antitrust and Wealth Inequality, 101 CORNELL L. REV. 1171 (2016) (challenging the idea that antitrust will make society more equal).

25 See infra subpart IV.C.

26 See John E. Kwoka, Jr., Does Merger Control Work? A Retrospective on U.S. Enforcement Actions and Merger Outcomes, 78 ANTITRUST L.J. 619, 636 (2013).

27 See U.S. DEP'T OF JUST., ANTTTRUST DIVISION POLICY GUIDE TO MERGER REMEDIES 6 (2011) [hereinafter 2011 MERGER REMEDY POLICY GuIDE], http:// 
The pervasive skepticism about administering breakups is overlooked in part because many judges, scholars, and antitrust authorities have asserted a preference for structural remedies over behavioral remedies. For long periods in antitrust history, courts viewed structural remedies as the best way to address anticompetitive mergers. As the Supreme Court observed over fifty years ago, "[d]ivestiture has been called the most important of antitrust remedies. It is simple, relatively easy to administer, and sure. It should always be in the forefront of a court's mind when [an anticompetitive merger] has been found." 28 In the ensuing decades, courts have left intact that basic idea that divestiture is the "most effective[ ] of antitrust remedies." 29

Antitrust enforcers are arguably the most important actors in determining remedies because of the Court's observation that "once the Government has successfully borne the considerable burden of establishing a violation of law, all doubts as to the remedy are to be resolved in its favor." 30 The two primary federal antitrust enforcers are the Federal Trade Commission (FTC) and the Department of Justice (DOJ). In the context of merger remedies, FTC officials have cited "less oversight by the agencies" as a reason for preferring structural remedies. ${ }^{31}$ In a 2004 guidance document, the DOJ reiterated that it prefers structural remedies "because they are relatively clean and certain, and generally avoid costly government entanglement in the market." 32

Those statements have left the impression that enforcers have retained a strong preference for structural remedies in merger review. In 2018, a federal judge considering a private lawsuit to break up a company that merged six years earlier observed that "the DOJ seeks divestiture in the vast majority of cases like this one."33 Putting aside for the moment the accu-

www.justice.gov/atr/public/guidelines/272350.pdf [https://perma.cc/T5RVVLWC].

28 United States v. E.I. du Pont de Nemours \& Co., 366 U.S. 316, 330-31 (1961) (footnote omitted).

29 See Steves \& Sons, Inc. v. JELD-WEN, Inc., 345 F. Supp. 3d 614, 648 (E.D. Va. 2018) (quoting E.I. du Pont, 366 U.S. at 326); In re Chi. Bridge \& Iron Co., No. 9300, 2005 WL 120878, at *50 (F.T.C. Jan. 6, 2005).

30 Ford Motor Co. v. United States, 405 U.S. 562, 575 (1972) (quoting E.I. du Pont, 366 U.S. at 334).

31 See Osinski, supra note 9.

32 U.S. DEP'T OF JUST., ANTITRUST DIVISION POLICY GUIDE TO MERGER REMEdIES 7 (2004) [hereinafter 2004 MERGER REMEDY POLICY GUIDE], http://www.justice.gov/ atr/public/guidelines/205108.htm [https://perma.cc/W873-DPE3].

33 Steves \& Sons, Inc., $345 \mathrm{~F}$. Supp. 3d at 648 (internal quotation marks omitted) (applying the Clayton Act in a private action). 
racy of that statement, ${ }^{34}$ the judge proceeded to reiterate the Supreme Court's characterization of antitrust law as viewing "divestiture [as] 'the remedy best suited to redress the ills of a competitive merger.' "35

For similar reasons as judges and enforcers, scholars have also often stressed the superiority of structural remedies. Structural remedies have the broadest support "in merger cases, where divestiture is the natural remedy for breaking apart what never should have been joined together in the first place." 36 The literature emphasizes that structural remedies are "administratively considerably easier in that, once divestiture has occurred, the agency's job is largely complete." 37

More recently, Lina Khan argued that structural remedies are superior to behavioral remedies in the context of a proposal for platform separation legislation. ${ }^{38}$ A separation mandate would, for instance, prevent Amazon from both operating an online marketplace and selling its own goods on that platform. Khan points out that structural separation regimes have been preferred to behavioral remedies because they are "highly administrable" and require less ongoing monitoring. ${ }^{39}$

Thus, even as some progressive antitrust scholars have called for a "new framework for holding private power to account," in which "[s]tructural remedies are to be preferred," 40 they engage with the issue of administering breakups, at most, in passing. In those brief discussions, they understandably echo in more modern contexts many of the same theoretical reasons why courts have long claimed to prefer structural remedies. In light of the pervasive preferences expressed for structural remedies, it is understandable why the deep-seated resistance to administering breakups has remained largely unacknowledged and unchallenged.

34 See infra subpart I.B.

35 Steves \& Sons, Inc., 345 F. Supp. 3d at 648 (quoting Caltfornia v. Am. Stores Co., 495 U.S. 271, 285 (1990)).

36 Spencer Weber Waller, The Past, Present, and Future of Monopolization Remedies, 76 ANTTRUST L.J. 11, 15 (2009); see also Steven C. Salop, Modifying Merger Consent Decrees to Improve Merger Enforcement Policy, 31 ANTITRUST 15, 18 (2016) ("Divestitures are the standard remedy to preserve competition potentially lost from the merger.").

37 Kwoka, supra note 26.

38 See Lina M. Khan, The Separation of Platforms and Commerce, 119 CoLuM. L. REV. 973, 980 (2019).

39 See id. at 985-86, 1063-64, 1074-75.

40 Tim Wu. The Utah Statement: Reviving Antimonopoly Traditions for the Era of Big Tech, MEDIUM: ONEZERO (Nov. 18, 2019), https://onezero.medium.com/theutah-statement-reviving-antimonopoly-traditions-for-the-era-of-big-teche6be198012d7 [https://perma.cc/JZN5-5J42]. 


\section{B. Hostility to Administering Breakups}

Despite the favored status of structural remedies in theory, antitrust breakups have become rare in practice. Part of the issue is that the statements of preference are relative rather than absolute-even if authorities preferred structural to behavioral remedies, they may prefer inaction to both of those remedies. Additionally, concluding that structural remedies are generally superior to behavioral remedies does not bind the government in any given case.

Another source of confusion is that in some antitrust contexts, divestitures are favored. Companies must obtain government approval for sizeable mergers, and authorities often condition approval on the sale of part of the combined business. ${ }^{41}$ However, those divestitures have, until recently, tended to be small-such as a handful of gas stations that would have resulted in local monopolies post-merger in specific towns. ${ }^{42}$ Whereas in a 1999 retrospective the highest price paid for divested assets as part of merger approval was "more than a hundred million dollars," 43 Instagram-if Facebook was forced to divest it-would reportedly fetch a price of over a hundred billion dollars. ${ }^{44}$

Even if large, pre-merger divestitures became common, they form part of a reorganization that still makes the divesting company bigger, not-as with breakups in other contextssmaller. Accordingly, although breakups can be of any size and arguably include divestitures ordered during merger review, the term will be used herein to refer to a significant breakup of a business outside of the merger approval process.

The government has not broken up one of the country's largest firms since 1982, when it split AT\&T into seven telephone operating companies and a long-distance carrier. ${ }^{45}$ However, the intellectual case against breakups had been building long before. Since at least the mid-twentieth century, courts have been wary of breaking up a unitary company. In a landmark 1953 case, United States $v$. United Shoe Machinery

\footnotetext{
41 See infra subpart II.B (reviewing studies of government divestitures).

42 See infra subpart IV.A.

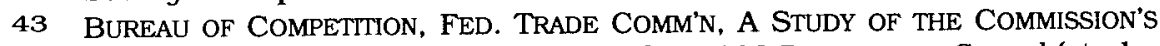
DIVESTITURE PROCESS 8, 18-19 (1999) [hereinafter 1999 DIVESTITURE STUDY] (studying use of divestitures during merger review).

44 See Bernard S. Sharfman, The Undesirability of Mandatory Time-Based Sunsets in Dual Class Share Structures: A Reply to Bebchuk and Kastiel, 93 S. CAL. L. REV. POSTSCRIPT 1, 5 (2019).

45 See United States v. AT\&T Co., 552 F. Supp. 131, 201, 224 (D.D.C. 1982).
} 
Corp., ${ }^{46}$ the court described the government's request to dissolve a shoe manufacturer into three separate companies as "unrealistic." 47 The court pointed out that United Shoe produced all shoes "at one plant in Beverly, with one set of jigs and tools, one foundry, one laboratory for machinery problems, one managerial staff, and one labor force. It takes no Solomon to see that this organism cannot be cut into three equal and viable parts." 48

Much of the intellectual foundation of the opposition to breakups comes from the Chicago School. These scholars have theorized that it is quite difficult to know what makes a firm appeal to consumers. ${ }^{49}$ For instance, is Apple popular because of its patents, clever marketing, the genius of Steve Jobs, or something else?50 Since courts and regulators are unlikely to be able to figure such questions out, a governmental breakup would risk ruining what consumers value most about the company. Thus, regardless of how monopoly power is obtained, once it exists, a breakup risks undermining consumer welfare. These scholars have also pointed out that this risk weighs against breaking up monopolies who gained and maintained their monopoly power by offering superior products rather than through anticompetitive conduct. ${ }^{51}$ The law does not allow for breaking up such companies. ${ }^{52}$ Stated otherwise, the government wants to avoid smashing success.

Scholars have also long criticized the government's realworld execution of breakups. ${ }^{53}$ The main evidentiary foundations of their concerns are twofold. First, many critiques stress the messiness of prior breakups. ${ }^{54}$ One cautionary tale is of

\footnotetext{
46110 F. Supp. 295 (D. Mass. 1953).

47 Id. at 348.

48 Id.

49 RICHARD A. POSNER, ANTTTRUST LAW 278 (2d ed. 2001); Harold Demsetz,
} Industry Structure, Market Rivalry, and Public Policy, 16 J.L. \& ECON. 1, 2-3 (1973); Sam Peltzman, The Gains and Losses from Industrial Concentration, 20 J.L. \& ECON. 229, 236-37 (1977).

50 See Ramsi A. Woodcock, The Antitrust Duty to Charge Low Prices, 39 CARDOZO L. REV. 1741, 1746 (2018).

51 See, e.g., Demsetz, supra note 49, at 4-5 (defending superior efficiency).

52 See infra subpart IV.C (explaining and challenging this stance).

53 See, e.g., Emanuel Celler, The Trial Court's Competence to Pass Upon Divestiture Relief, 10 ANTITRUST BULL. 693, 693 (1965) (describing criticisms of trial judges' competence to issue remedies of divestiture for antitrust violations, including being too busy or inexpert); Jerrold G. Van Cise, Limitations Upon Divestiture, 19 GEO. WASH. L. REV. 147, 147-48 (1950) (criticlzing the DOJ's pattern of too heavily searching for antitrust violators and too heavily relying on divestiture as a remedy).

54 See infra subpart II.A (reviewing scholarly discussions of past breakups). 
the 1970 dissolution of El Paso Natural Gas. ${ }^{55}$ After antitrust authorities obtained a judicial order to break up the company, implementation took seventeen years and three Supreme Court orders urging the parties to proceed "without delay." 56 Observers believe that these and other incidents raise doubts about competence, as 'courts' expertise lies in answering legal questions, not making [day-to-day] business decisions about questions such as pricing, product introduction, and investment in risky ventures." 57

A second foundation for skepticism of divestiture administrability comes from empirical research. Several studies of DOJ and FTC divestitures in the 1960s and 1970s found that few divestitures contributed to competition, with the earliest and most prominent of these examinations concluding that divestitures "could not be branded anything but a failure." 58

Despite an already emerging intellectual hostility to breakups, the government proceeded with breaking up AT\&T because it was an unusual case. The AT\&T monopoly was "substantially a creature of regulation and public intervention."59 As a result, even those opposed to government intervention in private enterprise could see a breakup of the company as consistent with their values. Moreover, the company had about ninety percent of the market for long-distance calls and owned many local telephone monopolies nationwide. ${ }^{60}$ Thus, if someone wanted to make a phone call to or from much of the country, the only option was AT\&T. ${ }^{61}$

In the face of that government-created monopoly, Stanford Professor William Baxter assumed leadership of the DOJ antitrust division and sought a dissolution. At the same time, Baxter was a "Chicago school economist"62 who thus preferred

55 See Michael C. O'Connor, Comment, Divestiture in Light of the El Paso Experience, 48 TEx. L. REv. 792, 792 (1970).

56 United States v. El Paso Nat. Gas Co., 376 U.S. 651, 662 (1964).

57 Howard A. Shelanski \& J. Gregory Sidak, Antitrust Divestiture in Network Industries, 68 U. CHI. L. Rev. 1, 34 (2001).

58 Kenneth G. Elzinga, The Antimerger Law: Pyrrhic Victories?, 12 J.L. \& ECON. 43, 47-53 (1969); see also Malcolm R. Pfunder, Daniel J. Plaine \& Anne Marie G. Whittemore, Compliance with Divestiture Orders Under Section 7 of the Clayton Act: An Analysis of the Relief Obtained, 17 ANTITRUST BULL. 19, 20-21 (1972) (raising "substantial doubt about" divestiture).

59 William E. Kovacic, Designing Antitrust Remedies for Dominant Firm Misconduct, 31 CONN. L. REV. 1285, 1303 (1999).

60 See Robert W. Crandall, The Failure of Structural Remedies in Sherman Act Monopolization Cases, 80 OR. L. REV. 109, 186 (2001).

61 See id.

62 Richard A. Epstein, The AT\&T Consent Decree: In Praise of Interconnection Only, 61 FED. COMM. L.J. 149, 155 (2008). 
minimal governmental intervention and emphasized efficiency. ${ }^{63}$ As he orchestrated the AT\&T breakup, Baxter established the principles that would help ensure that another would not happen for decades. ${ }^{64}$ Baxter declined to pursue breakups in a number of other cases-including IBM-and espoused a basic principle that "if 'there is no assurance that appropriate relief could be obtained,' then the government must question the value to consumers of prosecuting the antitrust case at issue." 65 That principle, created and embraced by scholars, became akin to a "Hippocratic oath for antitrust enforcers and jurists." 66

That new cautionary approach to remedies, and to antitrust overall, was put to the test in the DOJ's case against Microsoft in the 1990 s and early 2000 s. ${ }^{67}$ The company supplied the operating system for over eighty percent of computers and allegedly used that position to favor its own computer programs. ${ }^{68}$ For instance, it required PCs to install Windows and Internet Explorer. ${ }^{69}$ In 2000, the government proposed separating the company's operating system from its software applications-thus creating two entities. ${ }^{70}$ The district court agreed to a breakup, mentioning deference to the government on the issue of remedies after it established that Microsoft violated antitrust law. 71

The Microsoft district court's choice of a structural remedy attracted much attention among legal scholars. By the time the Court of Appeals considered the case in 2001, many scholars had weighed in not only through amicus briefs, but through law review articles that directly referred to the case. ${ }^{72}$ Robert Crandall's 2001 study looked at divestiture cases

63 See Lawrence Lessig, The New Chicago School, 27 J. LEGAL STUD. 661, 665 (1998).

64 See Shelanski \& Sidak, supra note 57, at 2.

65 Id. (quoting In re Int'l Bus. Machs. Corp., 687 F.2d 591, 594 (2d Cir. 1982)).

66 Id. n.5 (explaining how the new remedy "axiom has long influenced academic writings on antitrust and regulatory policy").

67 United States v. Microsoft Corp., 97 F. Supp. 2d 59, 64 (D.D.C. 2000), vacated, 253 F.3d 34 (D.C. Cir. 2001).

68 See Microsoft Corp., 253 F.3d at 73-74.

69 See id. at 45.

70 See id. at 48; Microsoft Corp., 97 F. Supp. 2d. at 62.

71 See Microsoft Corp., 97 F. Supp. 2d at 62.

72 See, e.g., Proposed Conclusions of Law of Amicus Curiae Robert H. Bork, United States v. Microsoft Corp., 97 F. Supp. 2d 59 (D.D.C. 2000) (No. 98-1232), 2000 U.S. Dist. Ct. Briefs LEXIS 14 (arguing that the findings of fact illustrate that Microsoft violated Section 2 of the Sherman Act); Brief of Professor Lawrence Lessig as Amicus Curiae at 1. United States v. Microsoft Corp., 97 F. Supp. 2d 59 (D.D.C. 2000) (No. 98-1232), 2000 U.S. Dist. Ct. Briefs LEXIS 3 (addressing "how the law of 'tying' applies to an alleged tie of software products"). 
against companies that-like Microsoft-had not obtained their monopoly power through mergers. ${ }^{73}$ It found that only in four or five cases had courts ever ordered divestiture. It then examined nine structural relief cases and concluded "that with one exception, ... there is very little evidence that such relief is successful in increasing competition, raising industry output, or reducing prices to consumers." 74 Moreover, in the lone exception-AT\&T-Crandall posited that behavioral remedies could have produced comparable results. ${ }^{75}$ Crandall concluded that structural remedies to address monopolies like Microsoft were unusual and very likely to fail. ${ }^{76}$

In another 2001 article, Howard Shelanski and Gregory Sidak analyzed the Microsoft context more directly and challenged the common remedy hierarchy in antitrust by observing that "ambitious structural remedies that incorporate supervisory and behavioral elements might require as much, or even more, continued judicial scrutiny as behavioral remedies require."77 They urged the Microsoft court to tailor the remedy to the context. ${ }^{78}$ That argument posed a challenge to breakups because behavioral remedies can be crafted that relate only to the anticompetitive conduct, whereas a breakup does not as directly address the anticompetitive action unless that action was a merger. Thus, Shelanski and Sidak's proposal implied that divestitures should only be applied to monopolies that obtained their dominance through prior mergers-unlike Microsoft. Also, Shelanksi and Sidak argued that the remedy must "advance economic welfare at the lowest possible social cost."79 A cost-benefit calculation was unlikely to provide support for divestitures under the prevailing zeitgeist because, as Richard Posner stated in a 2001 antitrust textbook, "Structural remedies such as divestiture are, as we know, slow, costly, [and] frequently ineffectual ...."80

In accordance with these and other scholarly views, the Court of Appeals overturned the remedy chosen. ${ }^{81}$ The court

\footnotetext{
73 See Crandall, supra note 60, at 109 .

74 Id.

75 Id. at $109,197$.

76 Id. at $197-98$.

77 Shelanski \& Sidak, supra note 57, at 54.

78 Id. at 3 ("[A]ny remedy should address the conduct for which Microsoft was found liable.").

79 Id.

80 POSNER, supra note 49.

81 United States v. Microsoft Corp., 253 F.3d 34, 98 (D.C. Cir. 2001) (revising also the scope of the liability). Four eminent economists argued that Microsoft should not be broken up because of administrability. See Remedies Brief of Amici
} 
acknowledged that divestiture "is indeed 'the most important of antitrust remedies" 82 but noted that, because, Microsoft had not obtained its monopoly power through anticompetitive mergers, it was appropriate to proceed cautiously before ordering a breakup. ${ }^{83}$

Several of the opinion's other points signaled a broader decline in the stature of breakups. The court directly dismissed the idea of deferring to the government after it had won its liability case. ${ }^{84}$ More ominously, it described divestitures as "radical" and argued that because Microsoft had not obtained its monopoly power through mergers, the "logistical difficulty" of splitting the company may weigh against divestiture. ${ }^{85}$ From the resistance to breaking up a single shoe production facility, courts had evolved to skepticism about breaking up a company even along two distinct but technologically linked product lines. Finally, the court seemed to adopt the view of prominent antitrust scholars encouraging a close tailoring of the remedy to the anticompetitive behavior. 86

By emphasizing that breakups' "long-term efficacy is rarely certain," 87 the court painted uncertainty as cause for skepticism about breakups. That emphasis underscores how the cost-benefit formulation weighs against breakups. It is easier to identify the costs of a breakup than the competitive benefits. After a breakup, there will often be clear increases in ongoing operating expenses because, for example, Facebook and Instagram would need to have two headquarters rather than one. Additionally, perhaps the most concrete and unavoidable category of costs in a breakup relates to the transition. Companies cover moving expenses; hire reorganization specialists, such as attorneys, accountants, and consultants; and absorb considerable employee time lost to managing and implementing the reorganization rather than producing the company's core product. ${ }^{88}$ Courts and enforcers must also devote resources to monitoring and overseeing the breakup. ${ }^{89}$

Curiae at 46-49, United States v. Microsoft Corp., 97 F. Supp. 2d 59 (D.D.C. 2000) (No. 98-1232).

82 Microsoft Corp., 253 F.3d at 105 (quoting United States v. E.I. du Pont de Nemours \& Co., 366 U.S. 316, 331 (1961)).

83 See id.

84 Id. at $80-81$.

85 Id. at $80,106$.

86 Id. at 107.

87 Id. at 80.

88 See, e.g., William M. Landes \& Richard A. Posner, Market Power in Anttrust Cases, 94 HARV. L. REV. 937, 953 (1981) (describing "heavy administrative" costs).

89 See Shelanskt \& Sidak, supra note 57 , at 32-34. 
In contrast, it is "axiomatic" that the competitive benefits of a breakup are difficult to predict.90 Relatedly, it is challenging to quantify the innovation and economic gains from two smaller, more nimble companies. ${ }^{91}$ Thus, whereas costs of a breakup are undeniable, inevitable, and identifiable, the benefits are inherently uncertain. Given that uncertainty, the Microsoft court's urging of "great caution"92 in adopting breakups-if taken literally-could alone make divestitures rare or nonexistent by imposing an impossible evidentiary burden on the government. Whether due to the court's resistance or political changes, the government subsequently decided not to pursue a breakup, instead settling for behavioral remedies. ${ }^{93}$

The shift in thinking about remedies in the early 2000s, albeit limited to merger remedies, can also be seen beyond the courts. In its 2004 Antitrust Division Policy Guide to Merger Remedies, the DOJ announced that "[s]tructural remedies are preferred to conduct remedies in merger cases." 94 However, in its 2011 policy guidance, the DOJ provided a more measured assessment of remedies in merger cases, declaring that "[i]n certain factual circumstances, structural relief may be the best choice to preserve competition." 95 Antitrust enforcers went from viewing behavioral remedies as "more difficult to craft, more cumbersome and costly to administer, and easier than a structural remedy to circumvent"96 in 2004 to seeing them as a "valuable tool" in 2011.97 That shift occurred under the administration of President Barack Obama, who had promised "to reinvigorate antitrust enforcement" by restructuring merger review. ${ }^{98}$

90 Cf. John M. Newman, Antitrust in Digital Markets, 72 VAND. L. REv. 1497,

1556 (2019) (describing the difficulty of predicting ex ante the effects of a merger).

91 See infra Part III (discussing possible diseconomies of scale).

92 Microsoft Corp., 253 F.3d at 80; see also Timothy J. Muris \& Jonathan E. Nuechterlein, First Principles for Review of Long-Consummated Mergers, 5 CRITERION J. ON INNOVATION 29, 47 (2020) ("II]f the government seeks to unwind a consummated merger, it must prove that the prospectwe benefits of that structural remedy outweigh the prospective harms, including the costs and unintended consequences that often arise from corporate de-integration and inevitably increase with time.").

93 See Microsoft Corp., 253 F.3d. at 98-103 (vacating the district court's remedies decree); infra section IV.B.1 (discussing political factors).

942004 MERGER REMEDY POLICY GUIDE, supra note 32.

952011 MERGER REMEDY POLICY GUIDE, supra note 27, at 4.

962004 MERGER REMEDY POLICY GUIDE, supra note 32, at 7-8.

972011 MERGER REMEDY POLICY GUIDE, supra note 27, at 6-7.

98 William E. Kovacic, Rating the Competition Agencies: What Constitutes Good Performance?, 16 GEO. MASON L. REV. 903, 904 (2009) (internal quotation marks omitted). 
A 2007 case illustrates the government's ambivalence regarding breakups. Seven years had passed since the anticompetitive purchase of a hospital, causing the FTC to decide against a divestiture out of concern about the "potentially high costs inherent in the separation." 99 In the same opinion, the FTC explained that "[d]ivestiture is the preferred remedy for challenges to unlawful mergers, regardless of whether the challenge occurs before or after consummation." 100

Thus, the rhetoric of preferring structural remedies sounds more expansive than it is in practice. Once a few years have passed since a merger, or the entities have integrated, the government is often reluctant to pursue a divestiture. In recent decades, the professed preference for structural remedies should have come with a caveat of "unless it would be costly or messy." 101

In short, deploying breakups as a remedy faces a considerable barrier beyond those that have been the focus in the budding literature fueling a revival of interest in antitrust. When observers compare breakups to unscrambling eggs, they are usually referring to the undoing of a consummated merger. ${ }^{102}$ Scholars and courts are even more resistant to splitting up companies in other contexts. ${ }^{103}$

This harsh view of breakups has larger implications for antitrust as an institution. Behavioral remedies are often costly and messy. ${ }^{104}$ The theoretical preference for structural remedies thus poses a dilemma for antitrust. Enforcers must ask "whether any remedy is sufficiently practicable to yield net benefits" to determine whether a case should be brought at all. ${ }^{105}$ In other words, the consensus is that if there is no practicable remedy, the government should leave the monopolist alone.

When the most practical remedy available-a breakup-is seen as a "clear[ ] . . . disaster"106 and "slow, costly, [and] frequently ineffectual," 107 the Hippocratic oath for antitrust en-

\footnotetext{
99 Evanston Nw. Healthcare Corp., 144 F.T.C. 375, 377 (F.T.C. 2007).

$100 \quad$ Id. at 523.

101 When consummated mergers are more recent in time, the preference may

hold.

102 See supra note 9 and accompanying text (discussing the egg metaphor).

103 See HERBERT HOVENKAMP \& PHILLIP E. AREEDA, ANTTTRUST LAW: AN ANALYSIS OF ANTITRUST PRINCIPLES AND THEIR APPLICATION 156 (2d ed. 1999).

104 See infra subpart IV.B.

105 Shelanskl \& Sidak, supra note 57, at 36 (emphasis omitted).

106 Clark, supra note 12 , at 775.

107 POSNER, supra note 49.
} 
forcers would direct authorities not to act.108 The primary scholarly critique of antitrust law is the fallure to act. ${ }^{109}$ As Chief Justice John Marshall observed in Marbury $v$. Madison, the government cannot be called a "government of laws ... if the laws furnish no remedy for the violation of a vested legal right." 110 The view of breakups as the best remedy, but unworkable, makes it less likely that antitrust authorities will take any action against monopolies. ${ }^{111}$

II

\section{THE WEAK EVIDENCE AGAINST AdMINISTRABILITY}

This Part examines the common assumption that breakups are too unwieldy by exploring its evidentiary foundations. The point is not to debate the competitive impact of divestitures. The goal is instead to understand the literature on the administrability of the breakup remedy. Even if we assume breakups would increase competition once implemented, what is the support for arguments that we cannot trust courts and agencies to manage the process effectively?

\section{A. The Limitation of Case Studies}

Narratives hold outsized influence on perceptions and beliefs. ${ }^{112}$ The narratives that loom largest in antitrust remedies are of the major historical breakups, which caused many observers to sour on divestiture as a remedy. ${ }^{113}$ This Section focuses on two of them. As "the mother of all monopolization

108 See Shelanski \& Sidak, supra note 57 (discussing the Hippocratic standard).

109 See John KWOKa, MERgers, MERGer CONTROL, AND REMEdiEs: A RETROSPECTIVE ANALYSIS OF U.S. POLICY 158 (2014) (stating that errors in "clearing anticompetitive mergers" are "[f]ar more common" than erroneous "challenges to competitively benign mergers"); Jonathan B. Baker, Jonathan Sallet \& Fiona Scott Morton, Unlocking Antitrust Enforcement, 127 YALE L.J. 1916, 1919 (2018) ("Concerns about the potential for under-enforcement are growing."); Herbert Hovenkamp, Post-Chicago Antitrust: A Review and Critique, 2001 Colum. Bus. L. REV. 257, 269 ("The biggest danger presented by post-Chicago antitrust economics is . . . that antitrust tribunals will be confronted with antitrust solutions that they are not capable of administering."); Khan \& Vaheesan, supra note 24, at 237 ("[T]he antitrust counterrevolution ... has produced monopolistic and oligopolistic markets and contributed to a captured political system . . . .").

1105 U.S. (1 Cranch) 137, 163 (1803).

111 See infra Part IV (discussing breakups among other remedies).

112 See ROBERT J. SHILLER, IRRATIONAL EXUBERANCE 13 (2d ed. 2005).

113 William E. Kovacic, Falled Expectations: The Troubled Past and Uncertain Future of the Sherman Act as a Tool for Deconcentration, 74 IOWA L. REV. 1105, 1149 (1989) ("Fresh memories of the deconcentration experiences of the 1970s have convinced many that the divestiture suit is a hopelessly flawed instrument of antitrust policy."). 
cases," 114 Standard Oil ${ }^{15}$ holds sway in scholarly conceptions of divestitures and is still debated. ${ }^{116} A T \& T,{ }^{117}$ as the most recent large breakup and "arguably the most significant antimonopoly case [in] the U.S.," ${ }^{118}$ presumably demonstrates the most advanced administration yet to be applied to a major government dissolution. Both of these historical breakups have been mentioned repeatedly in discussions of divestitures, even decades after they occurred. 119

The 1911 breakup of Standard Oil remains "iconic because it was the first time antitrust was used to break up a company, and at the time Standard Oil was the largest company in the United States." 120 In its appeal to the Supreme Court, the company argued that its unitary nature made a dissolution logistically impractical and dangerous to both the oil industry and the economy more generally. ${ }^{121}$ "There are many parts, but each part has its place, and if a part is taken out, the whole structure is disintegrated," the company predicted. ${ }^{122}$ Those warnings, if believed, would be fatal to breakups because antitrust seeks to increase the number of competitors and overall industry output. ${ }^{123}$ Divested pieces cannot provide those benefits if they cease to operate.

The company's defense is noteworthy because critics of breakups have long echoed it. Microsoft used similar arguments to overturn the court-ordered dissolution in 2001, citing the impracticability of undoing its "unitary" organization. ${ }^{124}$

114 Einer Elhauge, Defining Better Monopolization Standards, 56 STAN. L. REV. 253, 290 (2003).

115 Standard Oil Co. v. United States, 221 U.S. 1 (1911).

116 See Kovacic, supra note 59, at 1300.

117 United States v. AT\&T, 552 F. Supp. 131 (D.D.C. 1982), affd sub nom. Maryland v. United States, 460 U.S. 1001 (1983).

118 Howard Shelanskd, Antitrust and Deregulation, 127 YALE L.J. 1922, 1945 (2018).

119 See generally, e.g., Peter C. Carstensen, Remedies for Monopolization from Standard Oil to Microsoft and Intel: The Changing Nature of Monopoly Law from Elimination of Market Power to Regulation of Its Use, 85 S. CAL. L. REV. 815 (2012) (mentioning "Standard Oil" forty-four times and AT\&T thirteen times); Kovacic, supra note 113 (mentioning "Standard Oil" twenty-one times and "AT\&T" thirteen times).

120 Barak Orbach \& D. Daniel Sokol, Antitrust Energy, 85 S. CAL. L. REv. 429, 432 (2012).

121 Brief for Appellant at 191, Standard Oil Co. v. United States, 221 U.S. 1

(1911) (No. 725) [hereinafter Standard O1l Brief].

122 Id.

123 See John M. Newman, Procompettive Justifications in Antitrust Law, 94 IND. L.J. 501, 517 (2019) (critiquing an "output-only" approach).

124 Microsoft Corp. Brief at 47, 53, United States v. Microsoft Corp., 253 F.3d 34, 99 (D.C. Cir. 2001) (Nos. 00-5212 and 00-5213), 2001 WL 34153358. 
The Court of Appeals also referred to that argument in overturning the breakup order. ${ }^{125}$ One of today's leading progressive antitrust intellectuals, Fiona Scott Morton, has argued against tech breakups based on integration, saying that "[b]y the time any antitrust verdict is rendered, there will be one coherent Facebook and no divisions to divest."126

Standard Oil was correct that its breakup required "a number of complicated restructurings." ${ }^{127}$ The court order split the company into "eleven large production and distribution companies" and "forced the spin-off of several smaller refining companies, pipeline companies, and even a tank car company." 128 Nonetheless, the dissolution of Standard Oil proceeded "relatively smoothly even though most of the newly independent entities were deprived of the full-scale integration that Standard had argued was vital to their survival."129 Even critics of the breakup agree that the oil industry and the divested pieces of Standard Oil thrived in the years after the breakup. ${ }^{130} \mathrm{We}$ do not know what would have happened otherwise, but Standard Oil's "warnings of industrial apocalypse"131 turned out to be false.

To be clear, scholars still debate the efficiency benefits of the dissolution. ${ }^{132}$ And the structure of Standard Oil was not the worst-case scenario for divestitures. But the breakup succeeded, despite substantial restructuring challenges, in facilitating "the emergence of a number of substantial independent competitors-including Amoco, Chevron, Exxon, and Mobilwhere there had been but a single firm before." 133

Scholars have a more favorable impression of the competitive impact of the AT\&T divestiture than that of Standard Oil, with most thinking that AT\&T's divestiture was overall beneficial. ${ }^{134}$ However, its administration came under withering scholarly attack soon after completion. The main critique was

\footnotetext{
125 United States v. Microsoft Corp., 253 F.3d 34, 106 (D.C. Cir. 2001).

126 Scott Morton, supra note 7.

127 Kovacic, supra note 59, at 1301.

128 HOVENKAMP, supra note 103 , at 300.

129 Kovacic, supra note 59, at 1298.

130 See, e.g., Crandall, supra note 60 , at 112 (seeing limited impact).

131 Kovacic, supra note 59, at 1298.

132 See Michael Reksulak \& William F. Shughart II, Tarring the Trust: The Political Economy of Standard Oil, 85 S. CAL. L. REV. POSTSCRIPT 23, 31-32 (2012).

133 Kovacic, supra note 59, at 1300, 1302.

134 See, e.g., Crandall, supra note 60, at 186; Kovacic, supra note 59.
} 
targeted at the degree of court involvement. ${ }^{135}$ It took ten years to get from the government's original filing of the lawsuit to the divestiture order, "spanning four Congresses, three Presidents, and two U.S. district court judges." 136 That order then began a period of extensive court monitoring and follow-up legal battles. About "thirty-five to forty separate waiver requests were filed per year in the first eight years of the decree," often taking years to resolve. ${ }^{137}$ Some scholars have described the AT\&T divestiture as a "failure," either because of the extensive costs and delays of relying on the court or due to flawed decision making by government officials who were tasked with running a business. ${ }^{138}$ Like with Standard Oil, it is also impossible to know what would have happened had the government not broken up AT\&T. 139

As some perspective on these critiques, AT\&T involved perhaps the largest set of divestitures in history. ${ }^{140}$ It thus provides an extreme example of a large-scale and diffuse breakup. Moreover, as the discussion above illustrates, much of the administrability concerns center on the court's involvement. Thus, to the extent that the case furnishes arguments against breakups, it is against a breakup heavily managed by the courts.

This discussion is not meant to suggest that the Standard Oil, AT\&T, or other historical dissolutions were perfect. As with most any large-scale project from long ago, whether in the private or public sector, hindsight enables observers to identify improvements. However, it would be perplexing if these cases continue to shape perceptions of divestitures. They are decades, and in the case of Standard Oil over a century, old. Similarly, to cite the United Shoe impracticability of splitting up a single shoe factory as evidence of breakup ineptitude lacks analytic rigor and is anachronistic because today's large shoe companies no longer produce their shoes out of a single factory. ${ }^{141}$

135 See, e.g., Paul W. MacAvoy \& Kenneth Robinson, Losing by Judicial Pollcymaking: The First Year of the AT\&T Divestiture, 2 YALE J. ON REG. 225, 261 (1985).

136 Id. at 225.

137 Crandall, supra note 60 , at 114-15.

138 See MacAvoy \& Robinson, supra note 135, at 246 (citing judicial judgment mistakes); Shelanski \& Sidak, supra note 57 , at 53 (urging divestiture caution based on AT\&T).

139 See, e.g., Crandall, supra note 60, at 115 (exploring alternatives).

140 Kovacic, supra note 59, at 1302.

141 See Amit Singh, Nike Manufacturing and Supply Chain Strategies, MKT. REALIST (Oct. 17, 2019), https://marketrealist.com/2019/10/nike-manufactur- 
It should also give critics pause that decades after the breakup of AT\&T, which by all accounts was followed by innovation, lower prices, and considerable competition, leading antitrust and telecommunications scholars cannot agree on whether the breakup represented "a policy success or a policy failure." 142 At a minimum, the subsequent world leadership of U.S. telecommunications companies and the prosperity of oil companies indicates that even lengthy and messy breakups can still be followed by trailblazing innovation and intense competition. ${ }^{143}$ Especially without considering how better design could address any flaws in past breakup administration, the historical record of prominent divestitures should not be cited as reason to condemn large-scale breakups today.

\section{B. The Lack of Systemic Evidence}

Beyond case studies, several more quantitative examinations from the 1960s through the 1980s influenced observers to see divestitures as "notoriously ineffectual."144 The most recent and comprehensive study during that time period, by Robert Rogowsky, came to similar conclusions as the previous one that had painted a "bleak" picture of antitrust remedies. ${ }^{145}$ Rogowsky analyzed over one hundred government antitrust cases. ${ }^{146}$ Like the other early influential empirical studies; Rogowsky's did not analyze market data or consumer welfare. Instead, he identified success as a divestiture that "reestablishes the acquired firm (1) independent of the parent, (2) viable in the long run, and (3) adequately structured to be an effective competitor."147 Based on these characteristics, and other factors such as the length of time of the divestiture, Rogowsky classified seventy-five percent of the divestitures as either defi-

ing-and-supply-chain-strategies/ [https://perma.cc/5JLH-AL85] ("Nike's manufacturing network has over 525 factories in 40 countries.").

142 Christopher S. Yoo, The Enduring Lessons of the Breakup of AT\&T: A Twenty-Fwe Year Retrospective, 61 FED. COMM. L.J. 1, 2-3 (2008).

143 See James W. Brock, Economic Power, Henry Simons, and a Lost Antitrust Vision of Economic Conservatism, 58 S.D. L. REV. 443, 452 (2013) ("II]t is well to remember that the telecommunications revolution of recent years-wireless, cell, smartphones, satellite, etc.-exploded after the breakup of AT\&T's telecommunications monopoly in the 1980 s, not before.").

144 Clark, supra note 12, at 774; see also David Balto, Lessons from the Clinton Administration: The Evolving Approach to Merger Remedies, 69 GEO. WASH. L. REV, 952, 958 (2001).

145 See Robert A. Rogowsky, The Economic Effectiveness of Section 7 Relief, 31 ANTTTRUST BULL. 187, 212 (1986).

146 Id. at 189.

147 Id. at 190. 
cient or unsuccessful, with twenty-eight percent falling into the worst category, unsuccessful. ${ }^{148}$

Rogowsky's metrics for assessing divestitures merit closer scrutiny. Divestitures were labeled as unsuccessful if the purchaser of the vertically divested assets had over ten percent of the relevant market. ${ }^{149}$ Not only does owning this much of the market fall far short of proving a monopoly, but this example indicates the study's heavy reliance on industry structure to measure competition. This and other measures of competition used by Rogowsky, such as whether the purchaser was in the Fortune 200,150 have since been discredited as insufficient bases for establishing a lack of competition. ${ }^{151}$ Thus, Rogowsky labeled divestitures as unsuccessful for having characteristics that are well-known today to be perfectly consistent with a divestiture that improves competition.

Additionally, Rogowsky labeled as unsuccessful any divestiture that ordered an insufficient size of assets divested-called partial divestitures. ${ }^{152}$ Also, many cases were classified as unsuccessful because the DOJ or FTC did not order any divestiture, or ordered a token amount. ${ }^{153}$ In other words, if the enforcers had sought larger-scale divestitures, their success rate would have significantly improved by Rogowsky's metrics. A study that played an important intellectual role in arguments against divestitures instead is perhaps better viewed as indicating that the government should pursue more extensive breakups.

Using a different methodology, the event study, James Ellert's examination of divestitures through the 1970s drew similarly harsh conclusions. Ellert examined the shareholder returns of firms subject to antitrust divestitures before and after those interventions. ${ }^{154}$ If divestitures were successful, Ellert expected the divesting firms to offer lower stock market returns and dividends after the antitrust intervention relative to other companies not subject to such interventions. However, Ellert found no significant difference in the returns of

148 See id. at 189, 196, 212.

149 See id. at 189, 196, 218.

150 See id. at 196.

151 See generally, e.g., Herbert Hovenkamp, Introduction to The Neal Report and the Crisis in Antitrust, 5 COMPETTION POL'Y INT'L 219 (2009) (chronicling the structure-conduct-performance paradigm).

152 Rogowsky, supra note 145, at 195.

153 Id. at 209, 228.

154 James C. Ellert, Mergers, Antitrust Law Enforcement and Stockholder Returns, 31 J. Fin. 715, 715 (1976) (examining firms challenged between 1950 and 1972). 
divesting companies compared to the returns of companies with different outcomes, such as those whose antitrust cases were dismissed. ${ }^{155}$ Moreover, Ellert was unconvinced that anything the antitrust authorities did as part of their merger evaluation program effectively reduced any monopoly gains. Although the stock value of companies subject to antitrust suits dipped by $1.6 \%$, Ellert interpreted that drop as resulting from legal and other costs of such actions. ${ }^{156}$

Rogowsky's study helps clarify Ellert's findings. A large number of divestitures never happened, took many years to implement, or required divestiture of only a small slice of assets. ${ }^{157}$ Also, Ellert's interpretation of the $1.6 \%$ drop as being attributable to the costs of antitrust action is speculative and reflects an average loss. ${ }^{158}$ Ellert's study is consistent with some subset of more extensive and well-designed divestitures reducing stock market returns.

A final shortcoming in Ellert's methodology is the limited value of stock market returns as a metric of anticompetitive earnings. Anticompetitive activities may not always yield higher profits or increase the value of the firm. ${ }^{159}$ As a result, if the antitrust authorities' actions had improved competition, the improvements may not be seen in stock market returns.

Even assuming those earlier studies' methodologies were rigorous, there is further reason to doubt their findings' relevance today. The FTC examined the administration of U.S. divestitures of all merger orders between 2006 and 2012. ${ }^{160}$ The success rate for structural remedies was eighty percent, with success defined as ultimately at least restoring competition. ${ }^{161}$ Moreover, the unsuccessful cases resulted from the FTC divesting piecemeal assets. ${ }^{162}$ When the FTC instead divested an ongoing business operation, all of the divestitures

\footnotetext{
155 Id. at 715-16, 724.

156 Id. at $724,729$.

157 Rogowsky, supra note 145, at 195.

158 Ellert, supra note 154, at 724-29.

159 For instance, in theory, the firm may compete away the monopoly rents. Or, if employees (including executives) captured the rents for higher salaries, successful antitrust interventions would not hit shareholder profit. See Crane, supra note 24, at 1192 .

160 BuREau of COMPETtTion \& BuREAU OF ECON., FED. TRADE COMm'n, THE FTC'S MERGER REMEDIES 2006-2012 (2017).

161 Id. at 18 (horizontal mergers). A minority of cases required over two or three years. See id. at 15,18 .

162 See $i d$. at 1-2, 23-24 (including intellectual property, technology, brand names, research and development, and equipment).
} 
succeeded. ${ }^{163}$ Therefore, the category of divestitures most relevant to breakups consistently succeeded.

The success rate of pre-merger divestitures is not a perfect comparison in terms of administering breakups, in part because they tend to be smaller scale. ${ }^{164}$ Regardless, these findings further undermine the prior empirical studies many have cited as evidence that antitrust authorities administer structural remedies poorly. In particular, because they considered a much later timeframe, the FTC's studies appear to reflect enforcers' and courts' improved approaches to administering divestitures by incorporating lessons learned in the intervening decades. ${ }^{165}$

More recent quantitative studies provide mixed results. Based on stock market returns, an examination of European Union (EU) pre-merger divestitures concluded that divestitures did not lead to significant declines in the stock prices of the firms ordered to divest, but that rivals benefited from those divestitures. ${ }^{166}$ However, besides the weakness of stock market value as a metric of antitrust effectiveness, the authors' conclusions provide limited evidence for or against breakups as a remedy because they were most critical of the excessive use of partial divestitures as remedies. They believed enforcers should go further by fully blocking mergers, ${ }^{167}$ an intervention that is more akin to a large-scale breakup from a competitive perspective. Stock-market-based studies of uninhibited breakups could show a stronger impact on competition.

A central limitation of the above examinations is that they fail to deploy the most respected empirical mechanism for establishing causality: randomization. ${ }^{168}$ The difficulty of know-

163 Id. at 1, 5. Success meant competition "remained at its pre-merger level or returned to that level within . . . two to three years." Id. at 15.

164 See supra subpart I.B. Also, for a pre-merger divestiture order, the companies can refrain from pursuing the proposed merger if they think the ordered divestiture would be harmful. This means that the private sector retains a degree of discretion-a check on incompetent administration-that it lacks in the case of other types of antitrust divestitures. However, there is limited evidence that the private sector has rejected government-ordered divestitures, and it would in any case be difficult to know whether a private-sector rejection meant the anticompetitive dimensions of the deal had been removed. Arguably, to the extent the rejection rate is low, it may actually strengthen the case for governmental competence in designing effective divestitures.

165 See 1999 DIVESTITURE STUDY, supra note 43, at 39.

166 See Tomaso Duso, Klaus Gugler \& Burcin B. Yurtoglu, How Effective is European Merger Control?, 55 EUR. ECON. REV. 980, 995 (2011).

167 Id. at 1002.

168 Dale L. Moore, Recurrent Issues in the Review of Medical Research on Human Subjects, 1 ALB. L.J. SCI. \& TECH. 1, 8 (1991) (“[R]andomization is often 
ing the counterfactual thus undermines all of these antitrust empirics. One study addresses that methodological shortcoming by considering the Dutch government's use of randomization in ordering divestitures by gasoline companies of stations along major highways. ${ }^{169}$ The divested gas stations were found to lower prices by 1.3 to $2.3 \%{ }^{170}$ The narrow market context, hospitable nature of gas stations to ownership transfer, and foreign jurisdiction heavily limit these findings' relevance to U.S. divestitures. Nonetheless, the most methodologically rigorous study available for determining causality indicates that divestitures can improve competition in some contexts.

Finally, none of this review's empirical studies consider deterrence. ${ }^{171}$ If breakups deter firms from pursuing monopolistic mergers, they could improve consumer welfare even if the divestiture itself-analyzed narrowly in terms of the immediate price effects in the specific market-did not yield evidence of improved competition. As a result, some of the divestitures labeled "failures" by Rogowsky or found to have had only a minimal impact on stock price by Ellert could-once deterrence is taken into account-be viewed as successful.

In summary, the most influential studies shaping pessimism about governmental administration of breakups relied on questionable methodologies and are outdated. The research is limited by the lack of sophisticated quantification of the effects of divestitures on consumer welfare, the failure to consider deterrence, and the absence of large breakups in the past few decades. More recent studies even provide grounds for cautious optimism that larger, government-ordered divestitures may yield high success rates. Some additional comfort comes from the absence of disaster despite an array of government interventions to separate large firms-including electric companies, railroads, banks, movie theaters, and television companies, among others. ${ }^{172}$ In addition, bankruptcy courts

absolutely essential to a study's design as a means of ensuring against any bias in treatment assignment.").

169 Adriaan R. Soetevent, Marco A. Haan \& Pim Heljnen, Do Auctions and Forced Divestitures Increase Competition? Evidence for Retail Gasoline Markets, 62 J. INDUS. ECON. 467, 467-70 (2014).

170 Id. at 469.

171 See, e.g., Rogowsky, supra note 145, at 189 (empirical study of 104 merger cases did not account for any non-beneficial deterrence caused by antimerger enforcement). Over-deterrence is also problematic.

172 On these industries, see Roberta S. Karmel, Is the Public Utility Holding Company Act a Model for Breaking Up the Banks that are Too-Big-to-Fail?, 62 HASTINGS L.J. 821 (2011); Khan, supra note 38, at 1037-51; Barak Orbach, The Paramount Decrees: Lessons for the Future, 19 ANTTRUST SOURCE 1, 2-4 (2020). 
regularly order divestitures. The limitations in evidence despite diverse breakups demonstrate the speculative nature of claims about the government being too incompetent to administer breakups.

III

A BALANCED VIEW OF BREAKUPS

Given the limited evidentiary foundations for harsh perceptions of breakup administration, the hostility to that remedy deserves fresh examination. This Part widens the lens on breakups by situating them in their broader business and law enforcement contexts. The literature on private sector divestitures and the goals of antitrust regulation are in tension with core assumptions that breakups are too extreme, complicated, and harmful.

\section{A. Insights from Private Divestitures}

Antitrust scholars have largely ignored research concerning an even more numerous category of divestitures: those in the private sector. As a threshold matter, it is helpful to recognize the frequency of private divestitures. In the midst of a growing economy and strong stock market, a 2019 survey of senior corporate and private equity executives found that eighty-four percent of respondent companies were planning a voluntary divestiture within the next two years. ${ }^{173}$ Well over three thousand private divestitures occur each year. ${ }^{174}$ In contrast, the FTC listed only ten divestiture orders annually to alter proposed or consummated mergers in its latest divestiture study, or less than one percent of all mergers and acquisitions. ${ }^{175}$ If for no other reason, the universe of private sector divestitures merits attention because of the considerably larger volume of cases to study.

173 Paul hammes, EY, Global Corporate Divestment Study 2019 2, 4 (2019), https://assets.ey.com/content/dam/ey-sites/ey-com/en_gl/topics/divestment/ 2019/global_divestment_study_report.pdf [https://perma.cc/57PT-ASWF] (reporting survey results from 930 senior corporate executives and 100 private equity executives).

174 See Paula Loop, When a Piece of Your Company No Longer Fits: What Boards Need to Know About Divestitures, HARV. L. SCH. F. CORP. GOVERNANCE (July 27, 2017), https://corpgov.law.harvard.edu/2017/07/27/when-a-piece-of-yourcompany-no-longer-fits-what-boards-need-to-know-about-divestitures [https:// perma.cc/Z5AE-NXB5].

175 See 1999 DIVESTITURE STUDY, supra note 43, at 9. 


\section{Are Private Divestitures Too Different To Be Helpful?}

The antitrust scholarly omission of private divestitures is to some extent understandable. After all, there are many differences between the two types of divestitures. Most importantly, antitrust divestitures aim to lessen a potential source of monopoly profits, whereas private divestitures aim to increase the value (including the long-term profits) of the company. ${ }^{176}$ Antitrust scholars might resist comparisons due to that distinction-and because it changes the composition of divestitures-making it less likely, for instance, that private divestitures will create two horizontal competitors. ${ }^{177}$ Additionally, a portion of private sector divestitures are conglomerates selling unconnected businesses. These differences indicate boundaries for finding antitrust lessons in private divestitures.

However, to observe that there are differences between private and public divestitures, and that we must limit inferences accordingly, is to state the obvious. The more challenging question is how much the differences matter in light of the project. Since the project here is to shed greater light on antitrust breakups from a starting point of limited evidence, the existing differences warrant further examination.

Resistance to comparing public and private divestitures due to the prevalence of private equity sales of conglomerate pieces in private divestitures would reflect an outdated view. Even in the 1980s and 1990s, a large portion of private divestitures were not by conglomerates. ${ }^{178}$ Since then, the field has shifted considerably. Observers traditionally saw private divestitures as helping bring firms "back to their basics" by shedding peripheral assets, often during times of financial distress. ${ }^{179}$ Over time, executives have increasingly pursued larger divesti-

176 Consequently, antitrust breakups may be more likely to destroy shareholder value than strategic reorganizations-a possibility addressed below. See infra subpart III.C (discussing shareholder value and deterrence).

177 Relatedly, historically many divestitures were of bad assets, which are unlikely to weaken the firm's competitive position. See Michael C. Jensen, Eclipse of the Public Corporation, 67 HARV. BUS. REV. 61, 63 (1989).

178 Even in the 1980 s and 1990s, a large number of divested units operated in the same industry as the parent. Hsiu-Lang Chen \& Re-Jin Guo, On Corporate Divestiture, 24 REV. QUANTITATIVE FIN. \& ACCT. 399, 411 (2005) (finding that 36\% of divestitures between 1985 and 1998 were of assets within the same industry by two-digit SIC code). The percentage of non-conglomerate sales could be higher or lower than this figure, given the limitations of industry codes.

179 Donald D. Bergh, Restructuring and Divestitures, in OXFORD RESEARCH ENCYCLOPEDIA, BUSINESS AND MANAGEMENT 1, 6 (2017). See generally id. at 1-29 (summarizing the literature). 
tures for strategic reasons rather than to offload unproductive and peripheral parts. ${ }^{180}$ Strategic motives include cost-cutting, the advantages of a leaner organization for innovation, and long-term growth. ${ }^{181}$ Some businesses have become so large and unwieldy that they are beyond the point of gaining economies of scale, and their larger size instead creates diseconomies of scale-or increased costs resulting from their size. ${ }^{182}$

By way of illustration, in 2012 Pfizer announced it would divest about forty percent of its business as part of a refocusing on human medicine development. ${ }^{183}$ The company proceeded to shed assets that provided synergies in terms of research and distribution. It split off its animal health unit, which develops animal medicines, in a $\$ 13$ billion initial public offering (IPO). ${ }^{184}$ As another example, Hewlett-Packard executives opted for a breakup to respond to the increasing pace of technology-driven markets. CEO Meg Whitman described the strategy by observing, "Being nimble is the only path to winning." 185 The expansive motives for pursuing divestitures and the diversity of assets separated mean that private divestitures offer many case studies that are potentially relevant to various antitrust breakup contexts.

As to the observation that private divestitures differ by aiming to increase the firm's value, that distinction speaks more to the goals rather than to the administration. If the private sector demonstrates success splitting up large inte-

180 Moschieri \& Mair, supra note 17, at 399 (describing divestiture as "a means to correct or reverse previous strategic decisions [(for example, diversification)], or a proactive strategic option").

181 Bergh, supra note 179 , at 7-10 (listing motivations for enterprise-wide reorganizations).

182 See Jesse W. W. Markham, Jr, Lessons for Competition Law from the Economic Crisis: The Prospect for Antitrust Responses to the "Too-Big-To-Fail" Phenomenon, 16 FORDHAM J. CORP. \& FIN. L. 261, 315 (2011); see also Jeremy C. Kress, Solving Banking's "Too Big to Manage" Problem, 104 MinN. L. REv. 171, 208-09 (2019) ("A sizeable body of research refutes evidence of economies of scope in financial services.").

183 See Seemantini Pathak, Robert E. Hoskdsson \& Richard A. Johnson, Settling Up in CEO Compensation: The Impact of Divestiture Intensity and Contextual Factors in Refocusing Firms, 35 STRATEGIC MGMT. J. 1124, 1125, 1127 (2014); Michael J. De La Merced, Pfizer Spins Off Animal Health Unit in \$2.2 Billion I.P.O., N.Y. TIMES (Jan. 31, 2013, 5:56 PM), https://dealbook.nytimes.com/2013/01/ 31/pfizer-spins-off-animal-health-unit-in-2-2-billion-i-p-o/ [https://perma.cc/ 8Z4A-5DZV].

184 De La Merced, supra note 183; see also Imran Ahmed \& Kasra Kasraian, Pharmaceutical Challenges in Veterinary Product Development, 54 ADVANCED DRUG DELIVERY REVIEWS 871, 878-79 (2002) (noting some of Pfizer's developments).

185 Ovide, Lublin \& Mattioli, supra note 16. 
grated companies, that experience can provide insights into how or whether antitrust authorities should do something similar, even if the goals for the breakup are different. For instance, Fiona Scott Morton's skepticism about a FacebookInstagram breakup, based on the observation that those two companies would be integrated by the time the breakup occurred, echoes the view of many antitrust scholars. ${ }^{186}$ Indeed, following approved mergers, antitrust authorities have only secured two real post-merger divestitures since 2001 -and each occurred within three years of the merger. ${ }^{187}$ If the source of resistance is the degree of integration rather than the particular shape, it is relevant to probe how the private sector has approached the divestiture of companies integrated to a comparable degree.

A note is in order on what is meant by integrated. In the case of Facebook and Instagram, the most compelling integration that gives critics pause is the technical interface of platforms-such as the code that enables users on one platform to message users on another. ${ }^{188}$ Even if integrated, the two social media platforms would still under normal circumstances operate as distinct business units within the company, supported by common company-wide functions. Also, consumers would continue to be able to interact with the two integrated platforms as distinct products, in the sense of being able to use one and not the other.

If observers are searching for divestiture case studies to understand a given possible antitrust breakup, some of the tens of thousands of private sector breakups in recent years could-from an administration standpoint-offer some appeal. Many involve the separation of horizontal businesses, technology companies, and prior mega-mergers. Especially on the question of splitting up previously integrated digital companies, private divestitures offer arguably more relevant case studies than the AT\&T or Standard Oil breakups that tend to dominate antitrust discussions.

The point is not that any particular private sector divestiture is a clear model for any particular proposed breakup, such as the eBay-PayPal merger and subsequent divestiture as a

186 See Scott Morton, supra note 7.

187 See Patel, supra note 8, at 16, 19-20.

188 See Facebook to Integrate WhatsApp, Instagram and Messenger, BBC (Jan. 25, 2019), https://www.bbc.com/news/technology-47001460 [https:// perma.cc/5DGR-VZJV]. 
roadmap for Facebook-Instagram. ${ }^{189}$ Large divestitures, public or private, tend towards uniqueness. Observing that a given proposed private sector breakup is different from any given public sector breakup misses the point.

The point in discussing the integration-related resistance to the Facebook-Instagram breakup is to diagnose the type of concern that is prevalent in antitrust discussions of breakups. A big part of that broader resistance is not about the particularity of the proposed breakup at hand. Instead, many observers demonstrate an abstract and generalized concern about breaking up consummated mergers - or breaking up the company once it is integrated. ${ }^{190}$ Those concerns should be informed by a set of business questions about how costly, lengthy, and difficult it would be to break the particular company up-not the extent to which a prior merger is consummated or integrated.

In other words, for antitrust scholars to recognize what the field can gain from a more interdisciplinary perspective on breakups, it is necessary to exit the antitrust silo that inclines toward labeling private sector divestitures as different. A more productive approach is to examine whether the points of commonality yield insights. Although the differences are real, it would be misguided to use them as a justification for ignoring private divestitures altogether. Since the private sector has undertaken divestitures of integrated companies with great frequency, study of those undertakings can speak to key business assumptions that have implicitly shaped breakup skepticism.

\section{What Insights Might Private Divestitures Offer?}

One key difference between private sector and antitrust views of divestitures is how to view the downsides of splitting up an integrated company. Executives who are deciding whether to divest-and business scholars who study those divestitures-are less deterred by the associated risks and costs than observers of antitrust breakups. For instance, while the private sector also prefers to sell a separate business unit rather than one that is heavily intertwined, ${ }^{191}$ many strategic divestitures split integrated businesses whose information

\footnotetext{
189 See Bergh, supra note 179.

190 See supra subpart I.B.

191 See Irene M. Duhaime \& John H. Grant, Factors Influencing Divestment Decision-Making: Evidence from a Field Study, 5 StRATEgIC MGMT. J. 301, 302 (1984).
} 
technology systems have been intertwined for decades. ${ }^{192}$ Hewlett-Packard was a fully integrated company-the type of unitary company that deters courts and enforcers from breakups-when it decided to split into two roughly equal halves. ${ }^{193}$

Executives pursue such strategic breakups despite awareness of the expenses and complexity. ${ }^{194}$ Again, Hewlett-Packard executives predicted that the divestiture would take several years to complete, cost $\$ 1.8$ billion, require extensive administrative management, and cause great internal upheaval. ${ }^{195}$ They proceeded despite that awareness and produced two highly profitable companies. ${ }^{196}$

What about in the context of technology-heavy deals? Antitrust scholars have urged particular caution in pursuing postmerger breakups in that space. ${ }^{197}$ The private sector has no such reservations, pursuing a number of divestitures years after consummation. Examples include PayPal and eBay, which had technologically integrated their platforms by the time the combined company decided to split, and AOL-Time Warner. ${ }^{198}$

Shareholders provide another perspective because they also demonstrate relative comfort with divestitures. Following unprofitable mergers and acquisitions, shareholders regularly pressure their managers to undo those consummated mergers

192 See, e.g., Stephanie Overby, How CIOs Unravel IT Systems After a Business Divestiture, CIO (Feb. 25, 2014, 7:00AM), https://www.cio.com/article/ 2378617/how-cios-unravel-it-systems-after-a-business-divestiture.html [https:/ /perma.cc/8W5Z-M3NJ] (describing the Hess integration).

193 See Ovide, Lublin \& Mattioli, supra note 16 (describing the divestiture).

194 See Rui J. P. de Figueiredo Jr., Emilie R. Feldman \& Evan Rawley, The Costs of Refocusing: Evidence from Hedge Fund Closures During the Financial Crisis, 40 STRATEGIC MGMT. J. 1268, 1271, 1287 (2019) (summarizing prior research on the well-known costs of reorganizing).

195 See Chris Matthews, Here's How Much HP's Split is Going to Cost, ForTunE (May 22, 2015, 8:05AM), https://fortune.com/2015/05/22/hp-split-cost [https://perma.cc/KL53-JQQY]; Robert McMillan, Hewlett-Packard Officially Files to Split, WALl STREET J. (July 1, 2015, 7:06 PM), https://www.wsj.com/ articles/hewlett-packard-officlally-files-to-split-1435783640 [https://perma.cc/ G3MK-T4Z5].

196 See Ovide, Lublin \& Mattioli, supra note 16.

197 See, e.g., Patel, supra note 8, at 63 (concluding that technology mergers may be extremely difficult to separate after a significant amount of time from consummation); Scott A. Sher, Closed But Not Forgotten: Government Review of Consummated Mergers Under Section 7 of the Clayton Act, 45 SANTA CLARA L. REV. 41, 90 (2004) (explaining how in "high-tech markets, it is often impossible to separate out the assets of the merged parties following close").

198 On these mergers, see Bergh, supra note 179, at 1-2; Richard Pérez-Peña, Time Warner Board Backs AOL Spinoff. N.Y. TIMES, (May 28, 2009), https:// www.nytimes.com/2009/05/29/business/media/29warner.html [https:// perma.cc/2GUW-HRQB]. 
even years later. ${ }^{199}$ In contrast, as described above, antitrust authorities have consistently declined to undo an anticompetitive merger mistakenly approved, even though they acknowledge-as have many scholars - that such mistakes have occurred. $^{200}$ In other words, antitrust enforcers almost never fix their prior mistakes by breaking up a company, but shareholders regularly fix their managers' mistakes by forcing a breakup.

Administrative costs may be systematically higher in forced divestitures, which are inherently adversarial. Higher administrative costs would be expected, particularly if the parties frequently argue over details, requiring more court interventions and likely slowing the breakup down. These differences are real, but some context for them is helpful. Studies have found that private acquisitions are often subject to litigation-by one estimate, over ninety percent. ${ }^{201}$ Thus, private divestitures are subject to court delays. They also tend to last years and take longer than executives expect. ${ }^{202}$

The point here is not that private and public divestitures involve the same costs. Ignoring for the moment the possibility that higher antitrust breakup costs may be avoidable with effective regulatory design, ${ }^{203}$ large-scale breakups will inevitably be complex, expensive, and lengthy. Rather, the point is that the private sector perspective indicates that many antitrust observers may have inflated negative perceptions of the administrative costs by attributing what is unavoidable-or at least what also occurs in the private sector-to government incompetence. The real question should be whether the inescapably high costs of the breakup are worth the benefits:

The current antitrust analysis may underestimate those benefits. Some, if not most, breakups would be expected to create non-antitrust-related value through the types of efficiency and nimbleness that motivate private sector divestitures. To elaborate, non-antitrust benefits may remain unrealized due to factors such as agency costs, emotional bar-

199 See Donald D. Bergh \& Barton M. Sharp, How Far Do Owners Reach into the Divestiture Process? Blockholders and the Choice Between Spin-Off and SellOff, 41 J. MGMT. 1155, 1156 (2015).

200 See KWOKA, supra note 109; supra subpart I.A.

201 See Matthew D. Cain \& Steven Davidoff Solomon, A Great Game: The Dynamics of State Competition and Litigation, 100 IOWA L. REV. 465, 469 (2015).

202 See, e.g., Stephen Heidarl-Robinson \& Suzanne Heywood, Getting Reorgs Right, HARV. BUS. REV., Nov. 2016, at 84, 86 (reporting that eighty percent of executives thought the deal did not achieve success on time); supra note 195 and accompanying text (describing HP's lengthy divestiture).

203 See infra subpart IV.A (discussing breakup design). 
riers, or monopoly rents that outweigh the divestiture gains. ${ }^{204}$ Independent of those considerations, however, any number of current companies might benefit from divestitures without those benefits being sufficient to justify the costs of the divestiture. If it would cost a company $\$ 500$ million to implement a private divestiture, and the efficiency and innovation gains of the divestiture amount to $\mathbf{\$ 4 0 0}$ million, that company will not rationally choose to divest. However, if the government were to break up that company for independent antitrust reasons, the (non-antitrust) $\mathbf{\$ 4 0 0}$ million in efficiency gains would need to be added to the benefits side of the breakup-even though those gains would not be the motivating factor.

Whether or not that $\$ 400$ million would rightly be seen as lowering the costs of a breakup's administration is debatable but ultimately unimportant. In some contexts, those side benefits of breakups could offset even higher governmental costs of administering breakups. More importantly, current antitrust cost-benefit analysis could significantly underestimate the benefits of breakups because it pays so little attention to the gains illuminated by private sector divestitures.

Private sector divestitures also inform the high "failure" rate of antitrust divestitures in the 1950s through 1970s that tainted observers' assessments of the remedy. ${ }^{205}$ By most accounts, a large portion of all M\&A transactions have questionable value, with a representative study putting the failure rate at almost half of all deals. ${ }^{206}$ Scholars similarly conclude that private sector divestitures have "mixed results."207

Of course, the different metrics do not allow straight comparisons of success rates across antitrust and the private sector. ${ }^{208}$ However, both large private and antitrust divestitures are, at their core, about dividing a company into pieces. Thus, private sector success rates can provide perspective on overlapping issues faced in antitrust breakups. For example, when private divestiture failure rates are compared to evidence interpreted as proof that government breakups are costly, messy, and potentially failing, it may suggest that legal scholars un-

\footnotetext{
204 These topics are developed further infra subparts III.B. and IV.B.

205 See supra subpart II.B.

206 See Nicole Zadrazil, Othmar Lehner \& Heimo Losbichler, The Crucial Role of Time in M\&A Activities: An Inductive Exploration, 13 J. MOD. ACcT. \& AUDITING 350, 350-51 (2017) (reviewing the literature).

207 See Duhaime \& Grant, supra note 191, at 313.

208 See supra section III.A.1. Thus, one cannot conclude from private divestiture rates that antitrust breakups should occur with a particular frequency or success rate.
} 
fairly blamed unavoidable challenges on government incompetence. Business scholars who have described over seventy percent of private sector deals as "abysmal failures" do not recommend that executives abandon them. ${ }^{209}$ Instead, they view failures as opportunities to improve. ${ }^{210}$

The business sector's persistence in the face of many failed reorganizations has brought benefits in the case of divestitures. Studies have consistently concluded that divestitures overall increase shareholder value. ${ }^{211}$ The data also indicates that certain types of divestitures add significantly more value, particularly larger divestitures. ${ }^{212}$ If intellectuals had convinced business leaders to abandon large private divestitures based on the high failure rates evident in the 1980s, it would have hurt the economy on a large scale. Yet around that time intellectuals used flawed evidence of antitrust breakup failure to convince authorities to abandon that remedy. Consequently, competition may have suffered due to that faulty evidentiary interpretation.

Although differences must be considered in comparing corporate divestitures to antitrust divestitures, such comparisons should be made rather than ignored. Many important questions still remain unanswered in the business literature on divestitures. $^{213}$ Still, the private divestiture literature is far more expansive, recent, and rigorous than the corresponding antitrust literature.

Situating antitrust remedies in the broader context of private sector reorganizations shows how the picture painted of breakups has become distorted. The costs of breakups are not as high as antitrust scholars and judges commonly assume. Businesses regularly expend considerable funds on organizational streamlining and system updating. To estimate the accurate costs for an antitrust breakup, it would be necessary to count only those expenses that would not have otherwise been incurred. It would also be necessary to lower the estimated "cost" of administering breakups by the gains from efficiency and nimbleness, which are currently omitted from relevant antitrust remedy analyses.

209 See Roger L. Martin, M\&A: The One Thing You Need to Get Right, HARv. Bus. REV., June 2016, 42, 44 (providing M\&A advice despite high failure rates).

210 See, e.g., id. (recommending better oversight and skill transfer).

211 See Chris Veld \& Yulia V. Veld-Merkoulova, Value Creation Through SpinOffs: A Review of the Empirical Evidence, 11 INT'L J. MGMT. REviews 407, 409 (2009).

212 See id.

213 See Bergh, supra note 179 (reviewing the business literature). 
An isolated analysis also risks implying that complications and delays are the fault of courts and enforcers, rather than features of divestitures. Indeed, one of the factors driving some CEOs to pursue a reorganization is the belief that the company "needs to be shaken up." 214 Executives are even willing to divide a company up along new lines that do not reflect a prior merger.

That private sector mindset sits in stark contrast to the widespread conception of antitrust breakups of consummated mergers as "unscrambling the eggs." 215 Whereas nobody tries to unscramble eggs, sophisticated and successful business leaders routinely carve up their own integrated companies despite inevitable transaction costs and decades of evidence that many fail. The hostility to breakups is partly born of the disciplinary and academic silo in which breakup conversations have persisted.

\section{B. Shareholder Harm Is Not an Obstacle}

The Supreme Court has historically emphasized that "the Government cannot be denied the [divestiture] remedy because economic hardship, however severe, may result."216 Nonetheless, concerns about shareholders have persisted as a factor influencing the remedy choice. ${ }^{217}$ Indeed, in fighting the government's proposal of a breakup, Microsoft wanted the court to consider "[t]estimony from Goldman, Sachs \& Co. and from Morgan Stanley Dean Witter that dissolution would adversely affect shareholder value." 218 The district court declined to do so. However, in overturning the breakup order, the Court of Appeals mentioned the value of hearing such testimony about shareholder value. ${ }^{219}$ The rest of this Part shows why significant shareholder harm is unlikely to happen and may be economically desirable if it does.

If the concern about shareholders comes from fear of harm to people's retirement and savings, the evolving structure of equity ownership is relevant. Most publicly traded shares of

\footnotetext{
214 See Heidari-Robinson \& Heywood, supra note 202.

215 See supra note 9 and accompanying text.

216 See United States v. E.I. du Pont de Nemours \& Co., 366 U.S. 316, 327 (1961). Because it predates the Chicago School's ascendancy, this language does not reflect today's Court.

217 See United States v. Int'l Tel. \& Tel. Corp., 349 F. Supp. 22, 29-30 (D.

Conn. 1972), affd sub nom., Nader v. United States, 410 U.S. 919 (1973).

218 United States v. Microsoft Corp., 253 F.3d 34, 99 (D.C. Cir. 2001).

219 Id. at 98-99 (listing various sources of testimony that were improperly not heard).
} 
large companies now are owned by mutual funds and other institutional owners holding diverse stocks. As a result, the impact of any given breakup would be diluted for most shareholders. Additionally, if a breakup improved long-term market health-or immediately helped the monopoly's competitorsmost of a given monopoly's shareholders could benefit from a breakup even if the broken-up company's stock was hurt. Indeed, one of the leading studies found that although the prosecuted company's stock went down, its rivals' stock went up. ${ }^{220}$

Even if the concern is solely about an individual company's shareholders, a breakup does not mean that a portion of the company is eliminated. If Google is forced to sell YouTube or Facebook is required to divest Instagram, shareholders would receive a massive payment for that sale. ${ }^{221}$ Overall, the literature consistently shows that private divestitures "have a positive impact on the divesting parent's share price."222

There has been limited direct study of the effects on shareholders of breakups. Moreover, what few studies exist did not examine the ultimate question of how breakups would compare to other antitrust remedies. Nonetheless, the leading quantitative research into stock value following antitrust divestitures suggests that the organizational reconfiguration does not significantly drive the stock value down. ${ }^{223}$

Nor have the most far-reaching antitrust breakups necessarily hurt shareholders. In its failed Supreme Court appeal of dissolution, Standard Oil warned that dissolution would be calamitous to shareholders-a possibility that could not be ruled out with confidence at the time because such a case was unprecedented. ${ }^{224}$ But within a year of the court order to dissolve Standard Oil, the company's total stock value had increased. ${ }^{225}$ Within two years of the court-ordered divestiture, founder John D. Rockefeller's wealth tripled. ${ }^{226}$ It is impossible to know the counterfactual, but the breakup was not-as predicted by Standard Oil's lawyers-calamitous to shareholders.

\footnotetext{
220 Duso, Gugler \& Yurtoglu, supra note 166 (finding a transfer of monopoly rents).

221 See Sharfman, supra note 44.

222 Moschieri \& Mair, supra note 17, at 399.

223 See supra subpart II.B. (reviewing the literature).

224 See Kovacic, supra note 59, at 1301.

225 Malcolm R. Burns, The Compettive Effects of Trust-Busting: A Portfolio Analysis, 85 J. POL. ECON. 717, 732 (1977).

226 See Michael Reksulak, William F. Shughart II, Robert D. Tollison, \& Atin Basuchoudhary, Titan Agonistes: The Wealth Effects of the Standard Oil (N. J.) Case, 21 RES. L. \& ECON. 63, 64 (2004).
} 
Of course, because historical antitrust breakups were often poorly designed, more powerful antitrust divestitures may lead to different results. If most scholars are correct that the AT\&T breakup overall increased competition, ${ }^{227}$ that case study is illustrative. Despite the government's concern about shareholder hardship, ${ }^{228}$ AT\&T shareholders benefitted substantially following the breakup. ${ }^{229}$

How might breakups fail to harm shareholders even while improving competition? Maintaining a monopoly can be expensive. ${ }^{230}$ Instead of focusing on defensive protection of a dominant market position, firms in a competitive industry pursue greater adaptability and innovation. ${ }^{231}$ That renewal has the potential to grow the industry at a faster rate than in an industry dominated by a monopolist. Faster-moving companies may be even more important in light of the increasing pace with which technologies are requiring companies to adapt. ${ }^{232}$

Agency theory and organizational psychology help to explain this conundrum of effective antitrust breakups still increasing shareholder value. Senior managers have often pursued growth, especially through mergers and acquisitions, even when growth would not improve the company's value. ${ }^{233}$ Yet many companies hold those acquisitions even after it is clear that they were failures, only divesting them when forced to do so by shareholders. ${ }^{234}$ Agency theory helps explain how these divestitures demonstrate a misalignment of incentives: managers' compensation may depend on the size of the company, whereas owners care more about profit. ${ }^{235}$ Or executives may direct a large share of the monopoly rents toward salaries

\footnotetext{
227 Kovacic, supra note 59(describing scholars' perspectives).

228 United States v. Microsoft Corp., 253 F.3d 34, 102 (D.C. Cir. 2001).

229 Kovacic, supra note 59.

230 See, e.g., Crane, supra note 24, at 1188 ("Monopoly is not free money to corporations-it has to be purchased.").

231 See Robert E. Hoskisson, Albert A. Cannella, Jr., Laszlo Tihanyi \& Rosario Faraci, Asset Restructuring and Business Group Affiliation in French Civil Law Countries, 25 STRATEGIC MGMT. J. 525, 527, 532 (2004).

232 Cf. Eric D. Beinhocker, The Adaptable Corporation, MCKINSEY Q. 77, 82 (Apr. 2006) (describing how large companies "can sometimes become so complex that they go into gridlock and change becomes impossible").

233 Cf. Jensen, supra note 177 , at 61 (noting owner-manager conflicts).

234 See Jennifer E. Bethel \& Julla Liebeskind, The Effects of Ownership Structure on Corporate Restructuring, 14 STRATEGIC MGMT. J. 15, 15 (1993).

235 Robert E. Hoskisson, Richard A. Johnson \& Douglas D. Moesel, Corporate Divestiture Intensity in Restructuring Firms: Effects of Governance, Strategy, and Performance, 37 ACAD. MGMT. J. 1207, 1208-09 (1994).
} 
while the shareholders' portion does not offset the corresponding costs. ${ }^{236}$

Because the design of executive compensation structures has improved, CEOs' motivation to grow counterproductively is presumably lessened today compared to decades ago. ${ }^{237}$ Moreover, increasing external pressures on managers-including from activist shareholders ${ }^{238}$ - have presumably made it more likely managers will pursue value-creating divestitures. Nonetheless, the agency problem persists. ${ }^{239}$ There is also some evidence that organizational inertia and emotional factors may cause companies to hold onto assets that they would economically benefit from divesting. ${ }^{240}$

Another way of conceptualizing the potential benefits to shareholders is to view antitrust breakups as a tool of corporate governance to push executives away from self-serving acquisitions. ${ }^{241}$ A primary goal of corporate law is to align the incentives of shareholders and managers by, for instance, imposing a fiduciary duty on managers. ${ }^{242}$ Yet it is costly for shareholders to monitor and influence their agents in the firm-managers and directors-which helps explain why "[t]he problem of managerial agency costs dominates debates in corporate law." 243 By discouraging managers from pursuing growth that harms shareholders, or by encouraging beneficial divestitures, antitrust enforcers may benefit shareholders by addressing some harmful effects of high agency costs.

It is unclear what percentage of breakups would add value to shareholders by solving agency costs or otherwise improving the firm's performance. But recent empirical evidence indicates that when CEOs propose mergers, "there is a very large

236 See supra note 159 and accompanying text.

237 See David I. Walker, The Way We Pay Now: Understanding and Evaluating Performance-Based Executive Pay 8 (Bos. Univ. Sch. Law, Law \& Economics Working Paper No. 15-34, 2015) (describing how an upsurge in relative performance evaluation in executive pay arrangements focuses compensation on firmspecific performance).

238 On activists and management, see Elisabeth de Fontenay, Private Equity's Governance Advantage: A Requiem, 99 B.U. L. REv. 1095, 1097 (2019).

239 See Lucian A. Bebchuk, Alma Cohen \& Scott Hirst, The Agency Problems of Institutional Investors, 31 J. ECON. PERSP. 89, 90 (2017).

240 See Bergh, supra note 179 (reviewing the literature).

241 See Spencer Weber Waller, Corporate Governance and Competition Policy, 18 GEO. MASON L. REV. 833, 873-74 (2011) (discussing the relationship between antitrust and shareholder value).

242 See Megan Wischmeier Shaner, Officer Accountability, 32 GA. ST. U. L. REV. 357, 360-63 (2016).

243 Zohar Goshen \& Richard Squire, Principal Costs: A New Theory for Corporate Law and Governance, 117 CoLUM. L. REV. 767, 767 (2017). 
thumb on the scale that pushes all deals toward approval."244 It is plausible that a substantial portion of antitrust breakups would not harm shareholders, and many may even benefit them. Of course, it is not, and should not be, the goal of antitrust to break up a company to bring shareholders unrealized gains. Still, the evidence available suggests that any resistance to breakups out of concern for significant harm to shareholders rests on weak foundations.

Despite the absence of evidence of extreme harm to shareholders in the past, to the extent that a monopoly is earning considerable profits from its market dominance, lower stock value would be expected following at least some effective breakups. Putting aside for now the questions surrounding deterrence and fairness, ${ }^{245}$ what does the private sector literature on divestitures add to this issue?

As the primary tool for assessing corporate law and antitrust, efficiency would presumably weigh heavily in the comparison of shareholder interests to consumer welfare. ${ }^{246}$ Antitrust laws arguably already prioritize consumer welfare over the monopoly owners' interests. ${ }^{247}$ To that preexisting hierarchy, this Article has illuminated another efficiency contributor omitted from those analyses: Breakups can help ensure that managers only retain "assets for which [their firms] have a comparative advantage and sell assets as soon as another party can manage them more efficiently. ${ }^{248}$ That additional efficiency consideration further weakens the argument for letting shareholder harm obstruct breakups.

In summary, substantial valuation drops as a result of breakups are uncertain to happen and of little societal concern if they do. Indeed, as the next subpart shows, even if every future breakup harms monopolies' shareholders that result may be desirable for addressing monopolies.

244 James D. Cox, Tomas J. Mondino \& Randall S. Thomas, Understanding the (Ir)relevance of Shareholder Votes on M\&A Deals, 69 DUKE L.J. 503, 504 (2019).

245 Deterrence is discussed infra in subpart III.C. Those hit hardest would be concentrated shareholders, such as executives and founders of a given large firm, many of whom would have directly benefited from the antitrust violations or have the ability to monitor anticompetitive wrongdoing. Thus, disgorgement of their prior anticompetitive profits would be appropriate to better align incentives and beneficial from a fairness perspective.

246 See Jill E. Fisch, Measuring Efficiency in Corporate Law: The Role of Shareholder Primacy, 31 J. CORP. L. 637, 637-39 (2006).

247 See Ramsi A. Woodcock, The Antitrust Case for Consumer Primacy in Corporate Governance, 10 U.C. IRVINE L. REV. 1395, 1400 (2020).

248 Larry Lang, Annette Poulsen \& René M. Stulz, Asset Sales, Firm Performance, and the Agency Costs of Managerial Discretion, 37 J. FiN. ECON. 3, 4 (1995). 


\section{Costly Breakups May Increase Deterrence}

The discussion so far has questioned whether breakup costs are prohibitively high, especially viewed through the private sector lens on such costs. But the argument has yet to examine the predominant assumption in the literature that high breakup costs are unequivocally bad. ${ }^{249}$ Upon closer examination, that assumption is incomplete.

Of course, holding all else equal, it is desirable to expend fewer public resources and seek minimal waste to achieve the same antitrust goal. Nonetheless, to be effective, antitrust remedies must prevent companies from seeking to abuse monopoly power in the future. ${ }^{250}$ As mentioned above, however, the existing empirical critiques that labeled breakups a failure did not consider deterrence. ${ }^{251}$ In other words, the indictment of breakups is uninformed by what is arguably the field's main function, because "U.S. antitrust policy is primarily a deterrence system." 252

One reason for that omission is that the difficulty in measuring deterrence makes it impossible to draw firm conclusions. ${ }^{253}$ However, breakups must play a central role in the architecture of antitrust. Unlike in Europe, where "the civil fine is the tool of choice," 254 U.S. "antitrust laws do not now provide for a 'civil penalty' for monopolization." 255 Nor do antitrust enforcers exercise their ability to pursue disgorgement, which requires a monopoly firm to forfeit its illegal profits. ${ }^{256}$ The costs imposed by a breakup are thus a potential substitute for the deterrent effects of disgorgement and civil penalties. ${ }^{257}$

\footnotetext{
249 See supra subpart I.B. (reviewing the hostility to breakups).

250 George J. Stigler, The Economic Effects of the Antitrust Laws. 9 J.L. \& ECON. 225, 227 (1966).

251 See supra subpart II.B. Nor do leading examinations of antitrust deterrence necessarily consider breakups of existing monopolies.

252 Paul L. Joskow, Transaction Cost Economics, Antitrust Rules, and Remedies, 18 J.L. ECON. \& ORG. 95, 98 (2002).

253 Jo Seldeslachts, Joseph A. Clougherty \& Pedro Pita Barros, Settle for Now but Block for Tomorrow: The Deterrence Effects of Merger Policy Tools, 52 J.L. \& ECON. 607, 608 (2009).

254 Stephen Calkins, Civil Monetary Remedies Avallable to Federal Antitrust Enforcers, 40 U.S.F. L. REV. 567, 570 (2006).

255 Harry First, The Case for Antitrust Civil Penalties, 76 ANTITRUST L.J. 127, 127 (2009).

256 See Einer Elhauge, Disgorgement as an Antitrust Remedy, 76 ANTrTRUST L.J. 79, 79 (2009). Private parties could bring follow-on lawsults for damages, if judges allow. See John M. Newman, The Anttrust Jurisprudence of Neil Gorsuch, 45 FLA. ST. U. L. REV. 225, 242-48 (2017).

257 The substitute has the disadvantage of not being well calibrated in terms of the total amount and ability to affect executives personally.
} 
If remedies were only pursued when they imposed minimal burdens on companies, then there would be few downsides for companies pursuing anticompetitive mergers: in the worst case scenario they still gain because they keep the monopoly profits earned prior to the low-cost breakup. ${ }^{258}$

The current breakup paradigm also gives businesses a blueprint for strategically positioning themselves to avoid breakups. Scholars and courts have emphasized that although it is relatively easy to split a company up when it has merged but kept its operations separate, it would be unwise to break up those same companies once integrated. ${ }^{259}$ In 2012, an FTC Bureau of Competition director clarified in an official statement that the agency "is most likely to ... divest an autonomous, ongoing business unit that comprises at least one party's entire business in the relevant market." 260 That policy seeks to ensure that the divested "business unit contains all components necessary to operate autonomously, that it has operated autonomously, that it is segregable from the parent, and that the unit's buyer will be able to maintain or restore competition almost immediately." 261

Courts have offered related details for merging companies wishing to avoid a later breakup. If a business that merged illegally has been together for some length of time, the court will look at investments made after the merger that may be diminished by a breakup. In the case of two hospitals that merged seven years earlier in violation of antitrust law, for instance, the FTC found divestiture too costly because the combined company had invested in improvements to a cardiac surgery program and computer systems. ${ }^{262}$ A divestiture could cause delays in the surgery program and glitches in the computer systems. ${ }^{263}$

The implication from these guidance statements and court orders is that executives running a monopoly-whether built organically or through illicit mergers-can improve their chances of avoiding being broken up by integrating all business

258 Cf. Steven C. Salop, Merger Settlement and Enforcement Pollcy for Optimal Deterrence and Maximum Welfare, 81 FORDHAM L. REv. 2647, 2652 (2013) (applying decision theory to merger review).

259 See supra note 197 and accompanying text.

260 Richard FEINSTEIN, FED. TRADE COMM'N, Negotiating MERger REMEdies: STATEMENT OF THE BurEaU OF COMPETtTion OF THE FEDERAL TRADE COMMission 5 (2012), https://www.ftc.gov/system/flles/attachments/negotlating-merger-remedies/merger-remediesstmt.pdf [https://perma.cc/XLT4-CZBJ].

261 Id.

262 Evanston Nw. Healthcare Corp., 144 F.T.C. 375, 449 (F.T.C. 2007).

263 Id. at 522. 
units. The current framework incentivizes executives to make rapid investments, such as in common technological interfaces that link different parts of the company and ensure that no significant piece operates autonomously.

Anecdotal evidence points to such strategic positioning. In 2018, after a wave of calls to break up Facebook took particular aim at its acquisition of Instagram and WhatsApp, ${ }^{264}$ CEO Mark Zuckerberg announced plans to connect these platforms more closely. ${ }^{265}$ More generally, executives dislike breakups and often take steps to grow their companies even when it is unprofitable to do so. ${ }^{266}$ This aversion to breakups suggests that business leaders would take steps to prevent breakups.

Thus, there is reason to believe that companies strategically take steps post-merger to lessen the likelihood of authorities breaking them up in the future. ${ }^{267}$ Such maneuvering may help explain the dearth of breakups, particularly if savvy businesses are able to integrate more quickly than antitrust authorities can learn that a merger was anticompetitive. Although other reasons to integrate exist, excess integration motivated by breakup avoidance is wasteful. Excess integration is thus doubly harmful, through both short-term higher costs and long-term thwarting of antitrust. Yet these skewed incentives are omitted from the recent literature on breakups. ${ }^{268}$

Additionally, it is difficult, if not impossible, for executives to rigorously identify harms to the company caused by excess integration, such as making the business "too big to manage." 269 While identifying the more concrete potential benefits of avoiding a breakup and costly reorganization is easier, the indeterminacy of estimating breakup effects makes it impossible to know whether antitrust currently over-deters or underdeters. $^{270}$ There is a risk of over-deterring, which could prevent

264 See, e.g., John Micklethwait, Margaret Talev \& Jennifer Jacobs, Trump Says Google, Facebook, Amazon May Be 'Antitrust Situation', BloomBERG (Aug. 30, 2018, 9:56 PM), https://www.bloomberg.com/news/articles/2018-08-30/ google-under-fire-again-on-search-as-hatch-calls-for-ftc-probe [https:// perma.cc/SA2Y-AEBM].

265 BBC, supra note 188.

266 See supra note 233.

267 For an application of decision theory to antitrust remedies, see Salop, supra note 258 .

268 See, e.g., Patel, supra note 8, at 44 (expressing only the opposite concern of disincentivizing prompt or complete integration for fear of the costs of a mandatory breakup).

269 Cf. Kress, supra note 182, at 195-200, 203 (discussing the managerial problems caused by size in several major financial firms).

270 See Calkins, supra note 254, at 568 \& n.4; Salop, supra note 258, at 2649. 
some beneficial mergers or investment in innovation. However, the weight of the evidence suggests that antitrust enforcers have been more likely to err on the side of underenforcement. ${ }^{271}$ This Article's demonstration of the underappreciated analytic and institutional resistance to breakups strengthens the case for concluding that the current antitrust framework under-deters. ${ }^{272}$

In the extreme, in theory costly breakups could be preferable to low-cost breakups if the benefits of improving deterrence outweigh the administrative waste. From a more realistic perspective, the implication is that the unavoidable costs of breakups can provide societal benefits by discouraging anticompetitive mergers and inefficient integration. To be clear, enforcers should not purposefully make breakups extra costly. ${ }^{273}$ But understood as a byproduct of improving firmlevel efficiency, deterrence, and competition, substantial breakup administration costs can contribute to an optimal antitrust policy.

IV

IMPLICATIONS

The statutory root of antitrust authority, the Sherman Act, did not specify divestiture as a remedy. ${ }^{274}$ Instead, that authority flows from courts' equity powers, and 'is flexible and capable of nice 'adjustment and reconciliation between the public interest and private needs as well as between competing private claims." 275 As a result, a shift toward viewing breakups as administrable can immediately improve antitrust without changing statutes or upending doctrine. Breakup administration also speaks to possible legislative reforms to antitrust that could better address monopolies.

\section{A. Administering Breakups}

In assessing breakups as a remedy, the question is how the government might perform today rather than how it performed decades ago. The literature on private sector breakups emphasizes that divestitures' success varies depending on the design

271 See KWOKA, supra note 109; Shapiro, supra note 22.

272 On the broader topic of deterrence inconsistencies, see Ramsi A. Woodcock, Inconsistency in Antitrust, 68 U. MIAMI L. REV. 105, 159 (2013).

273 A monetary penalty would be preferable for adding deterrence to breakups.

274 Sherman Antitrust Act of 1890, 26 Stat. 209 (codified as amended at 15 U.S.C. $\S \S 1-38)$.

275 Zenith Radio Corp. v. Hazeltine Research, Inc., 395 U.S. 100, 131 (1969) (quoting Hecht Co. v. Bowles, 321 U.S. 321, 329-30 (1944)). 
and management of the process. ${ }^{276}$ Three principles are important for designing the administration of antitrust breakups: leveraging business sector expertise, streamlining court involvement, and remaining open to large breakups.

The first of these principles, business expertise, is important in light of perhaps the primary source of resistance to breakups: "Judges aren't good at breaking up companies."277 Observers are right to doubt courts' competence in administering such day-to-day business decisions. However, that critique of breakups reflects an antiquated understanding of governance.

Since the last large-scale breakup, many agencies have evolved toward what scholars have described as "new governance" and "collaborative" methods of regulation. ${ }^{278}$ These and related concepts speak to regulatory process design and are most closely associated among legal scholars with administrative law. ${ }^{279}$ In the context of breakup administration, this model of governance would encourage the regulator to leverage private-sector expertise and knowledge rather than recreating it. ${ }^{280}$ The Environmental Protection Agency (EPA), Consumer Financial Protection Bureau (CFPB), and other agencies now pervasively rely on large businesses to develop internal selfregulatory processes, often through a compliance department or third-party inspectors. The agencies then monitor or manage the firm's internal self-policing infrastructure. ${ }^{281}$

These new governance models allow the agency to benefit from the firm's skill in designing the best path to achieving a regulatory goal. ${ }^{282}$ A key design feature is establishing a regular dialogue with regulated entities, in which the regulator learns about and assesses the process and outputs. ${ }^{283}$ Viewed through this more expansive new governance lens, the government's competence in designing and managing breakups

276 Christian Thywissen, Ulrich Pidun \& Dodo zu Knyphausen-Aufse $\beta$, Process Matters-The Relevance of the Decision Making Process for Divestiture Outcomes, 51 LONG RANGE PLANNING 267, 278-79 (2018).

277 Spangler, supra note 6.

278 See Freeman, supra note 21 (discussing collaborative governance).

279 See supra note 21 and accompanying text.

280 See Jody Freeman, The Private Role in Public Governance, 75 N.Y.U. L. REV. 543,549 (2000).

281 See Van Loo, supra note 20, at 401 ('[T] he firm's compliance team essentially serves as the regulatory monitors' agents.").

282 See Rory Van Loo, The Missing Regulatory State: Monitoring Businesses in an Age of Surveillance, 72 VAND. L. REV. 1563, 1603-04 (2019).

283 Id. 
should not be the determinative factor in assessing whether breakups are administrable.

By some measures, the FTC has been slower than other agencies in shifting toward new governance. For instance, whereas the CFPB and EPA have about as many lawyers as monitors (which are called examiners or inspectors), the FTC enforces the law almost entirely through lawyers. ${ }^{284}$ However, the FTC appears open to relying on private parties, such as independent third-party monitors in divestitures. ${ }^{285}$ Assuming a large gap exists between the FTC's tactics and regulatory best practices, the differences should lend further confidence that improvements in its historic approach to breakups are possible by moving closer to administrative best practices.

How would these principles translate into administering breakups? Space constraints do not allow for a comprehensive sketch of the process, but the literature in finance, strategy management, and business organization provides insights into how to administer breakups more effectively. Success factors include involving middle managers in implementation ${ }^{286}$ and adopting an effective communication campaign with employees. ${ }^{287}$

Antitrust enforcers should not be expected to become experts on these various details, although hiring industry divestiture experts as antitrust agency employees would help. Enforcers can to some extent leverage the monopoly's internal reorganization capabilities, but relying on a self-serving firm's workforce as the main source of business expertise would be a mistake. Thus, enforcers can increase the chances that the breakup benefits consumers by requiring the firm to pay for outside reorganization experts.

Hiring outside experts to run the breakup is essential because research into private, voluntary divestitures supports the commonsense notion that "serial divesters," or firms that regularly divest, perform far better at divestitures. ${ }^{288}$ Yet the dearth of large-scale antitrust breakups means that antitrust enforcers lack such experience, including the ability to identify

\footnotetext{
284 See Van Loo, supra note 20, at 410-411.

2851999 DIVESTITURE STUDY, supra note 43, at 29.

286 See generally Danielle Nees, Increase Your Divestment Effectiveness, 2 STRATEGIC MGMT. J. 119, 120-21 (1981).

287 C. Gopinath \& Thomas E. Becker, Communication, Procedural Justice, and Employee Attitudes: Relationships Under Conditions of Divestiture, 26 J. MGMT. 63, $63(2000)$.

288 Mark Humphery-Jenner, Ronan Powell \& Emma Jincheng Zhang, Practice Makes Progress: Evidence from Divestitures, 105 J. BANKING \& FIN. 1, 15 (2019).
} 
what key information the firm may be hiding that is crucial to a successful divestiture. ${ }^{289}$ Nor are monopolies themselves likely to be serial divesters even if their advice could be trusted. Hiring outside experts brings serial divestiture expertise into the process because those entities have experience in designing effective reorganizations and knowing what information they must request from a firm to make effective decisions.

An inevitable challenge is that reorganization experts specialize in adding value to the firm rather than promoting competition. Again, the literature on new governance proves instructive. To some extent, a similar argument could be made about other industries - that firms specialize in making profits, not in enforcing the law-so why situate compliance within the firm? Part of the answer is that the goal is to build on as much private sector expertise as possible before adding the public regulatory layer. Another way of thinking about this is that a reorganization is difficult enough; whether the third-party consultants can help with 10 percent or 90 percent of the process, leveraging business knowledge is better than ignoring it.

Moreover, the enforcer and trustee would still be involved in managing the plan's design in an iterative process. There would thus ideally be a team component to the breakup administration process that weighs various options from both perspectives. The enforcer brings the deeper understanding of what would improve competition that the private sector consultants may lack.

That reporting structure speaks to a related concern. The close working relationship with the monopoly in developing the breakup plan risks industry capture of the process. A captured third-party expert or regulator could encourage breakups that place excess weight on increasing the value of the firm. To address that risk, the monopoly should be required to pay for the third-party experts, but not be allowed to choose them-or at least it should not have the final word. Moreover, the thirdparty experts should agree not to serve the firms involved in the divestiture for a certain number of years afterwards to avoid conflicts of interest. Additionally, it would reduce capture potential that the consultant would report to and need to have its breakup plan approved by the FTC, DOJ, or other government representative. These and other adjustments would need to be implemented into the design of breakup administration to ad- 
dress the unavoidable challenges in such a large-scale publicprivate undertaking.

Although third-party reorganization services can cost millions of dollars, firms often hire such experts when they voluntarily merge and reorganize. ${ }^{290}$ Regardless, imposing additional expenses alongside the breakup could help fill the gap of civil penalties in addressing monopolies, thereby making divestitures more deterrent. ${ }^{291}$ The purpose is not to increase the breakup's costs, but the deterrence upside potentially makes such administration-improving costs more acceptable.

To some, a privatized breakup process will seem suboptimal. Whether it would be preferable for administrative agencies to have the capabilities to design and oversee the day-today details of breakups is debatable. Similarly, judges would benefit from having the resources and competence to swiftly rule on objections from the monopolist along the way. But that world does not exist and creating it would require massive government overhauls and increases in public expenditures.

The more relevant question is whether the addition of third-party reorganization expertise-which can be implemented without doctrinal, organizational, or expenditure changes-is a substantial improvement over breakups run by government authorities with limited expertise and resources. More generally, to reject breakups based on either an assumption that the government must do everything or a mistrust of collaborative governance would be to hold antitrust to a different standard than other regulators face. ${ }^{292}$

The second principle is to streamline the court's involvement in designing and implementing the breakup as much as possible. Avoiding protracted legal wrangling about the details is important because one of the biggest administrability critiques of breakups is excess delay. ${ }^{293}$ A similar problem has motivated new governance models that aim to move from an adversarial to a cooperative relationship. ${ }^{294}$ Rather than the agency and firm fighting through court orders to hand over

290 See Kenton Kivestu, The Unit Economics of Consulting: How Much Do McKinsey, BCG and Bain Charge Clients, ROCKETBLOCKS (June 16, 2020), https:// www.rocketblocks.me/guide/business-model.php [https://perma.cc/FU6392D6] [noting that a typical twelve-week strategy case can cost upwards of $\$ 1.25$ million for consulting firms such as McKinsey or BCG).

291 See supra subpart III.C.

292 See generally, e.g., Freeman, supra note 21, at 33-66 (providing regulatory examples).

293 See supra notes 135-39 and accompanying text (discussing delay concerns).

294 See Freeman, supra note 21, at 22. 
information, the goal is a problem-solving approach in which the firm and the regulator work together towards a common compliance goal. ${ }^{295}$

Both the regulator's authority and its approach are relevant when it seeks to avoid repeatedly going to court over many details of the breakup. Of course, the monopoly should have a means of weighing in on and submitting evidence about the choice of remedy and the shape of the breakup. At the same time, courts should exercise their discretion to avoid what Microsoft had requested: "substantial discovery, adequate time for preparation and a full trial on relief." 296 When courts grant such broad requests by deep-pocketed companies, they greatly increase the costs of pursuing a breakup. The monopoly thus succeeds in making that particular case more difficult for resource-strapped enforcers and in weakening the intellectual argument for breakups by providing yet another example of a bogged down, expensive case.

Although many approaches might streamline court involvement, a straightforward path would be to return to the long-established tendency to defer to the enforcers' remedy design. 297 That approach makes more sense in light of what Rebecca Haw Allensworth has identified as the "adversarial economics" problem in antitrust, in which courts struggle to determine the winner of the "battle of the experts" hired by each party. ${ }^{298}$ One of Allensworth's solutions is to provide courts with access to third-party expert testimony. ${ }^{299}$ Another way of conceptualizing the hiring of third-party reorganization experts is as addressing this dueling economists problem, but outside of the delay-filled court process.

To further improve expediency and expertise, the court should also delegate considerable process administration to a court-appointed trustee, ideally one with deep antitrust and private sector divestiture experience. In recent years, courts have increasingly relied on these parties-sometimes called a

295 Id.

296 United States v. Microsoft Corp., 253 F.3d 34, 103 (D.C. Cir. 2001). Prior to Microsoft, after finding antitrust liability, courts were more willing to defer to agencies on the question of remedy. See id.

297 See United States v. E.I. du Pont de Nemours \& Co., 366 U.S. 316, 334 (1961).

298 See Rebecca Haw, Adversarial Economics in Antitrust Litigation: Losing Aca demic Consensus in the Battle of the Experts, 106 Nw. U. L. REV. 1261, 1299 (2012).

299 Id. at 1293. 
special master or monitor-to oversee antitrust remedies. ${ }^{300}$ The trustee has unrestricted access to the monopoly and communicates to the DOJ or FTC any anticompetitive conduct observed. ${ }^{301}$ These court-appointed monitors have in many fields become a standard means to "police the firm" following court orders. ${ }^{302}$

The regulatory structure for breakups would thus be best understood as the trustee running the day-to-day process, subject to veto by the antitrust enforcer. The trustee and enforcer would oversee a private sector workforce of third-party reorganization experts paid for by the monopoly, in addition to the monopoly's internal experts who inform the breakup plan. Courts would provide a check on the process but should only become involved in unusual circumstances once the breakup process is underway, with heavy deference to the enforcer and trustee-run plan. Perhaps court involvement would be mostly limited to situations in which the enforcer disagreed with the trustee, or some high bar such as abuse of discretion. Those limits are important to ensure that the breakup process stays streamlined.

A third principle for effective administration is removing the government inhibition about pursuing far-reaching breakups. One of the most consistent findings in the empirical literatures on both private and antitrust divestitures is that smaller divestitures leave the separated assets with insufficient resources to compete. ${ }^{303}$ Additionally, smaller divestitures may leave the monopoly too large and fail to produce a sufficiently fragmented industry. ${ }^{304}$

Antitrust authorities appear to have internalized some of those lessons in the past few years. Aside from speeches proclaiming as much, ${ }^{305}$ enforcers in 2018 required the largest

300 See D. Daniel Sokol, Policing the Furm, 89 NOTRE DAME L. REV. 785, 835-36 (2013).

3011999 DIVESTITURE STUDY, supra note 43, at 29-30.

302 Veronica Root, The Monitor-"Client" Relationship, 100 VA. L. REv. 523, 527 (2014).

303 See Duso, Gugler \& Yurtoglu, supra note 166, at 1002; Rogowsky, supra note 145 , at 209.

304 The FTC's own study of merger approvals concluded as much, since all of its divestltures of ongoing businesses succeeded, "suggesting that the more limited scope of the asset package increases the risk that a remedy will not succeed." FED. TRADE COMm'N, supra note 160, at 5.

305 See Makan Delrahim, Assistant Attorney Gen., U.S. Dep't of Just., Keynote Address at American Bar Association Antitrust Fall Forum (Nov. 16, 2017), https://www.justice.gov/opa/speech/assistant-attorney-general-makandelrahim-delivers-keynote-address-american-bar [https://perma.cc/6QLYCYU2]. 
divestiture ever, a $\$ 9$ billion divestiture as a condition for approving the Bayer/Monsanto merger, and negotiated another sizeable divestiture to DISH as part of the Sprint/T-Mobile deal. ${ }^{306}$ Granted, those large merger-approval divestitures are few and amount to a fraction of the size of what the sale of Instagram would be. ${ }^{307}$ Thus, those deals are of limited relevance to the debates about breaking up some of today's largest companies. Nonetheless, the trend toward larger pre-merger divestitures indicates that antitrust enforcers may recognize the benefits to competition of larger divestitures.

Ironically, the reluctance since the 1980 s to push for large breakups stems in part from a fear of messing something up. ${ }^{308}$ But by holding back out of fear of mistakes, enforcers make it less probable that those divestitures will succeed as ongoing businesses. Rather than avoiding damage, the antitrust Hippocratic Oath can sometimes cause harm. ${ }^{309}$ Courts and enforcers must be willing not only to pursue breakups, but also to design them to fully address the problem-by analogy, to remove the entire cancerous tumor rather than only part of it.

This discussion is not meant to provide an exhaustive list of administrative best practices. For instance, it would also be ideal to consider accompanying breakups with penalties, to the extent that the costs of a breakup are deemed insufficient for optimal deterrence. Nor should the discussion be taken as suggesting that antitrust breakups as described here would be a straightforward undertaking. Like any private reorganization and any government intervention in private affairs, they would often prove messy and imperfect.

Nonetheless, there is no doubt that the historical approach to administering breakups can be meaningfully improved upon-a process that has already begun. Moreover, as antitrust enforcers gain experience administering breakups, they will become better process supervisors. ${ }^{310}$ In addition to lever-

306 Recent Proposed Judgment, DOJ Approves T-Mobile/Spring Merger Under Dish Network-Entry Theory-Proposed Final Judgment, United States v. Deutsche Telekom AG, No. 19-cv-02232 (D.D.C. July 26, 2019), 133 HARV. L. REV. 739, 741 (2019); Arthur J. Burke, Ronan P. Harty, Jon Leibowitz, Howard Shelanski \& Jesse Solomon, Davis Polk Discusses Largest U.S. Antitrust Divestiture in BayerMonsanto Deal, CLS BLUE SKY BLOG (June 13, 2018), https://clsbluesky. law.columbla.edu/2018/06/13/davis-polk-discusses-largest-u-s-antitrustdivestiture-in-bayer-monsanto-deal/ [https://perma.cc/33HY-YUH7].

307 See supra note 44 and accompanying text.

308 See supra subpart I.B (explaining the origins of hostility to breakups).

309 On the Hippocratic Oath, see Shelanski \& Sidak, supra note 57, at 2.

$310 C f$. Humphery-Jenner, Powell \& Zhang, supra note 288. 
aging existing private sector experience, regulators should adopt the prevailing corporate mindset of recognizing glitches as parts of a worthwhile process. Unavoidable setbacks provide opportunities to improve administration rather than reason to abandon a remedy that is well within modern collaborative regulators' sphere of competence.

\section{B. Choosing Breakups}

This Article's main implication concerns enforcers' and courts' perception of breakups. The predominant discomfort with breakups as a remedy is rooted in two misperceptions. The first is that the government is disastrous at administering breakups. The second is that the risks of a breakup are tremendous. Neither of these is supported in the literature, particularly once breakups are viewed in terms of how they would and should be administered today, rather than how they were implemented decades ago.

As a result, at the very least, there is a need for greater openness to deploying breakups. As part of this increased openness, courts should view with great skepticism dire predictions that breakups will destroy shareholder value, consumer welfare, the industry, or the economy. Faced with a government breakup, businesses have historically developed self-serving estimates that later proved to be wrong. ${ }^{311}$

The question then becomes how much more than openness is warranted. Is there support for a regulatory or judicial default assumption that breakups are the superior remedy? Once a firm has violated antitrust law, choosing a remedy amounts to a prediction of whether breakups would be superior to alternatives.

\section{Comparing Breakups to Access Remedies}

This section focuses on mandated access, an alternative remedy in the post-merger context. However, much of the analysis is relevant to other behavioral remedies and to other liability contexts. The focus on access mandates reflects their prevalence in recent breakup conversations as the leading alternative suggested instead of breakups. Some critiques of AT\&T's dissolution emphasize that a better solution would have been to mandate that AT\&T allow competitors to use its 
telephone network. ${ }^{312}$ Also, instead of splitting Instagram from Facebook, one of the prominent proposed alternative remedies is to require "that Facebook enable open interconnection between itself and any new market entrant." 313 The preference by many for this alternative is rooted in a skepticism about breakups' administrability, even in the post-merger context. ${ }^{314}$ Additionally, access remedies are more appealing than other behavioral remedies in the post-merger context because there may be no conduct to prohibit moving forward that would address the prior merger.

Comparing access remedies to breakups is a context-specific undertaking, and thus attempting to declare one remedy as superior to the other overall would be of limited value. Access remedies have the potential to improve consumer welfare, particularly in the context of financial and technology platforms or when a breakup would destroy what consumers value most in a company. ${ }^{315}$ Moreover, breakups and access remedies together will sometimes be necessary. ${ }^{316}$

It would nonetheless be a mistake to view breakups as inherently more costly and messy than access remedies simply because two merged companies have integrated. Scholars have pointed out that access remedies require ongoing "sophisticated oversight and dispute resolution mechanisms that typically exceed the resources and strengths of the enforcement agencies." 317 Although the perception of bad experiences with breakups soured antitrust decision makers, "our experience with conduct remedies has also not been satisfying, and there is little reason to think that such decrees work any better in monopolization cases." 318 In the most recent large-scale case

312 See Crandall, supra note 60, at 186-189; Epstein, supra note 62, at 161-63.

313 Scott Morton, supra note 7.

314 See, e.g., id. ("Simply divesting Instagram from Facebook is unlikely to work.").

315 See Rory Van Loo, Digital Market Perfection, 117 Mich. L. REV. 815, 836-39 (2019); Rory Van Loo, Making Innovation More Compettive: The Case of Fintech, 65 UCLA L. REv. 232, 234, 242-44 (2018).

316 If separated from Instagram after showing the merger had been anticompetitive, Facebook might still be found to undermine competition-at which point mandating interoperability with other social networks may prove valuable. For an in-depth treatment of Facebook emphasizing behavioral remedies, see Dina Srinivasan. The Antitrust Case Against Facebook: A Monopolist's Journey Towards Pervasive Surveillance in Splte of Consumers' Preference for Privacy, 16 BERKELEY Bus. L.J. 39, 81-82 (2019).

317 Spencer Weber Waller, Access and Information Remedies in High-Tech Antitrust, 8 J. COMPETITION L. \& ECON. 575, 575-77 (2012).

318 HERBERT HOVENKAMP, THE ANTITRUST ENTERPRISE: PRINCIPLE AND EXECUTION 301-02 (2008). 
that included access remedies, Microsoft was involved with the court for sixteen years, until 2011.319 Thus, a similar narrative of administrative messiness can be crafted about access remedies as exists for breakups.

Moreover, given the outdated antitrust view of breakups, many observers may have compared access remedies implemented recently with breakups administered decades ago. A more rigorous comparison would reflect how enforcers would administer breakups today-by leveraging private sector expertise. ${ }^{320}$ Within that proper frame of reference, there is no strong evidentiary basis that access remedies are more administrable.

Nor do those arguments in favor of access remedies consider the types of economic gains identified in this Article for breakups. The antitrust analysis sees the benefits of intervention in terms of consumer welfare and the remedies as part of the costs. However, to those consumer welfare benefits, breakups as a remedy add the extraneous societal gains of nimbler, more efficient firms. ${ }^{321}$ Included in those overlooked benefits are the reorganization and systems upgrade expenses that can be handled during the breakup and that even a well-run monopoly would have undertaken anyways. ${ }^{322}$ Access remedies, and indeed behavioral remedies overall, do not provide those additional benefits. For large monopolies, breakups' added efficiency could be substantial.

These additional considerations may be enough to tip the remedy scale in breakups' favor in many cases. But given the dearth of recent data points available, the empirical case for a breakup preference is weak. The safe stance would therefore be to declare that the remedy analysis should be undertaken from a place of neutrality. A neutral starting point defers the choice of remedy to future sophisticated cost-benefit analyses tailored to the facts of a given case.

There are risks in adopting a facially neutral approach, however. Neutrality towards remedies would be ideal if the remedy analysis were truly objective, informed by the interdisciplinary empirics relevant to breakups, and able to adjust for deterrence. However, arguably the primary "dilemma facing

319 See United States v. Microsoft Corp., 159 F.R.D. 318, 338 (D.D.C. 1995); Press Release, U.S. Dep't of Justice, Microsoft Antitrust Final Judgment Expires May 12 (May 11, 2011), https://www.justice.gov/opa/pr/microsoft-antitrust-flnal-judgment-expires-may-12/ [https://perma.cc/6BXN-T7PV].

320 See supra subpart IV.A.

321 See supra Part III.

322 See supra Part III. These can instead be seen as reducing breakups' costs. 
antitrust enforcers is to balance the costs and benefits in a world without perfect information." 323 In all likelihood, faced with the monopoly's sophisticated economic argument against breakups, in many cases the government's economists will fail to establish any particular remedy as definitively preferable. ${ }^{324}$

As a result, despite the intention to remain objective, the decision will still often come down to a judgment call. Behavioral economics has shown that unrecognized biases influence even experts' decisions. ${ }^{325}$ Institutions and ideologies resist change, and even what people conclude from scientific experiments depends partly on what their preconceptions have taught them to see. ${ }^{326}$ Moreover, wealthy firms exert considerable influence on the political process and consistently argue against breakups. ${ }^{327}$ The most influential actors in the private sector would thus overall be expected to steer antitrust policy away from breakups. Of course, officials may still choose breakups under intense public or political pressure, such as that surrounding their ongoing investigations of Amazon, Facebook, and Google. ${ }^{328}$ But in the absence of such extraordinary influence, the psychologically and politically attractive choice for an unsure enforcer may be to settle for a remedy other than a breakup. A purportedly neutral approach risks amounting to a de facto preference for remedies other than breakups. ${ }^{329}$

Is a de facto default to behavioral remedies desirable? In theory, a behavioral remedy default allows for lighter antitrust intervention. A preference for behavioral remedies is thus appropriate when there is concern about over-enforcement or over-deterrence. However, if scholars are correct that antitrust faces the opposite problem, there are institutional design foundations for a default to breakups.

323 Rogowsky, supra note 145 , at 191.

324 Cf. Allensworth, supra note 298, at 1293-1303 (explaining adversarial antitrust economics).

325 See Stephen J. Choi \& A.C. Pritchard, Behavioral Economics and the SEC, 56 STAN. L. REV. 1, 25-27 (2003).

326 ThOMAs S. KuHn, THE StRucture of Scientific REVolutions 113 (1962).

327 See, e.g., Elizabeth Pollman \& Jordan M. Barry, Regulatory Entrepreneurship, 90 S. CAL. L. REV. 383, 400 (2017) (explaining how market position can provide leverage with government); Matthew C. Stephenson \& Howell E. Jackson, Lobbyists as Imperfect Agents: Implications for Public Policy in a Pluralist System, 47 HARV. J. ON LEGIS. 1, 19 (2010) (linking lobbying to a status quo bias).

328 See Jacob M. Schlesinger, Brent Kendall \& John D. McKinnon, Hunting for Giants, WALL ST. J., June 8, 2019, at Al.

329 Or, more precisely, a de facto default to remedies other than breakups. 
Additionally, more ex post breakups can improve ex ante identification of harmful mergers. Because firms proposing a merger have far more extensive information than do antitrust authorities, they are in a better position to predict whether a given merger will later prove anticompetitive. By pursuing the remedy that firms dislike the most, ex post breakups can cause firms to internalize the costs of anticompetitive mergers. Holding enforcers' merger approval process constant, ${ }^{330}$ an increase in ex post breakups would therefore overall add more of the private sector's sophistication to determining which mergers should not move forward due to anticompetitive concerns. ${ }^{331}$ The potential to better calibrate antitrust diagnostics supports a breakup default.

Institutional design considerations also apply when administering the remedy. Even with a flawless design, access mandates usually require ongoing oversight. Consequently, executives can retain their monopoly power if they can sufficiently outmaneuver regulatory monitoring. More broadly, there are many different ways to abuse monopoly power. As a result, beyond policing a firm for a specific behavioral remedy, the government must have mechanisms for policing that same firm for different violations.

A breakup that addresses monopoly power, rather than leaving it intact, offers the greatest potential to avoid both of those ongoing sources of regulatory oversight. The private sector has greater resources and sophistication than antitrust authorities, whose budgets have not grown-or have shrunkeven as the markets they regulate expanded considerably. ${ }^{332}$ Access remedies requiring enduring government involvement are therefore more in tension with agencies' resource and sophistication limitations than are breakups, which offer a clear end point. ${ }^{333}$

330 Of course, for ex post breakups to improve antitrust they must not cause public regulators to invest less in ex ante screening for problematic mergers. An extreme breakup default could overall harm antitrust if it caused authorities to defer the pre-merger approval process until later. However, given the current starting point of extreme resistance to breakups and heavy industry influence in politics, such a swing is unlikely and could be addressed if it materializes rather than using such an argument as a reason to avoid a clear improvement.

331 Antitrust relies on both public and private actors for enforcement. See, e.g., Steves \& Sons, Inc. v. JELD-WEN, Inc., 345 F. Supp. 3d 614, 648 (E.D. Va. 2018) (considering private suits to enforce antitrust law).

332 See Rory Van Loo, The New Gatekeepers: Private Firms as Public Enforcers, 106 VA. L. REV. 467, 510-11 (2020).

333 Industry can later consolidate-thus the need to prevent and deter. 
Another institutional limitation on antitrust authorities is that their leadership is subject to sudden changes in the political process when new presidential administrations arrive. Consequently, a monopoly subject to behavioral constraints could wait for a more deregulatory political regime to assume control of antitrust enforcement, at which point the monopolist could petition for lax monitoring or fewer restraints. ${ }^{334}$ Relatedly, the monopoly's efforts to capture enforcers are more constant than public attention. That asymmetry in pressure and the subtle nature of regulatory monitoring make access mandates vulnerable to erosion.

Breakups are inherently more resistant to the political process. ${ }^{335}$ Granted, the changing of presidential administrations complicated the government's decision not to continue pursuing a breakup of Microsoft following the appeal. ${ }^{336}$ Still, once a breakup is executed a future pro-monopoly FTC, for instance, cannot simply reconstruct the prior monopoly. Thus, breakups may be more likely to succeed because they require less monitoring by both the enforcer and the public.

Finally, breakups are the more market-oriented remedy. Those arguing for inaction or the continuation of more cautious antitrust enforcement often reason that dynamic competition will ultimately unseat even monopolies. ${ }^{337}$ That view weighs in favor of conduct over structural remedies, because markets have the chance to respond to inevitable imperfections in the breakup administration. In contrast, with access remedies, private actors face a sustained non-market constraint. Those putting faith in markets, and dynamic competition, should thus find that mandated breakups driven by the private sector are the more appealing antitrust remedy.

The case for a breakup default is strongest in the case of consummated mergers. It may thus be worth shifting the burden of proof onto the party arguing against breakups in the post-merger context. Moreover, as Steven Salop has argued,

334 See supra subpart III.C.

335 But see Frank H. Easterbrook, The Limits of Antitrust, 63 TEX. L. REV. 1,15 (1984) ("TT]he economic system corrects monopoly more readily than it corrects judicial errors.").

336 Harry First \& Andrew I. Gavil, Re-Framing Windows: The Durable Meaning of the Microsoft Antitrust Litigation, 2006 UTAH L. REV. 641, 688.

337 See Shelanski \& Sidak, supra note 57, at 10-11 (describing classic antitrust theory). For an application of market forces to the division of assets, emphasizing the ease of forced intellectual property licensing, see Ramsi Woodcock, Antitrust's Messy Breakup Fallacy, WHAT AM I Missing? (Jan. 15, 2019), https:// zephyranth.pw/2019/01/15/antitrusts-messy-breakup-fallacy [https:// perma.cc/3GTZ-9TYB]. 
antitrust authorities should consider requiring divestitures of the company even if the divested pieces are unrelated to the original anticompetitive merger. ${ }^{338}$ That principle is crucial in the context of a monopoly's acquisition of a nascent competitor, which may have halted the competitor during the sole window of time comprising any true threat. ${ }^{339}$

Should breakups be the default remedy beyond the postmerger context? Although a universal antitrust breakup default for non-merger cases is unwarranted, the traditional deference to enforcers' choice of remedy seems sensible-even if the remedy is a breakup. In choosing a remedy, however, enforcers should consider the factors mentioned above-the challenges of policing monopolies for behavioral remedies, need for deterrence, and broader economic benefits of breakups. Enforcers and judges should then make the final decision based on what would most help consumers and society rather than which remedy most closely fits the wrong.

\section{Comparing Breakups to Inaction and Other Alternatives}

Space constraints do not allow for devoting similar attention to comparing other alternatives, but a few brief notes are in order. Other alternatives include financial penalties, regulation outside of antitrust, and inaction. Financial penalties are difficult and impractical to set at a deterrent level. ${ }^{340}$ These and other alternatives are worthy of sustained examination, and in some contexts one or several of them combined may be superior to breakups. However, overall, conduct prohibitions and penalties are less promising than other remedies for addressing the full costs of the anticompetitive merger.

In terms of regulatory interventions outside of antitrust, new legal rules would be needed for many such proposals for

\footnotetext{
338 See Salop, supra note 36 , at $18-19$.

339 For a discussion of Facebook making defensive acquisitions, see C. Scott Hemphill, Disruptive Incumbents: Platform Competition in an Age of Machine Learning, 119 COLUM. L. REV. 1973, 1987 (2019).

340 See Maurice E. Stucke, Morality and Antitrust, 2006 COLUM. BUS. L. REV. 443,475 . The present value of future monopoly gains is speculative and presumably large. Moreover, given enforcement costs and imperfect detection, optimal deterrence would likely need to exceed the full costs to the monopoly. Margaret Guerin-Calvert, Keith N. Hylton, Daniel L. Rubinfeld, Gregory J. Werden, Koren Wong-Ervin \& Terry Calvani, Some Thoughts on Cartel Sanctions, ANTITRUST SOURCE, June 2019 , at 1,2 . That level of fine may shut down the company and harm consumers overall. For a general review of deterrence theory and applications to antitrust, see generally Keith N. Hylton, Punitive Damages and the Economic Theory of Penalties, 87 GEO. L.J. 421 (1998).
} 
oversight, such as treating online platforms as utilities. ${ }^{341}$ Thus, those outside-of-antitrust alternatives may not be practical-making the real choice between an antitrust remedy and no intervention.

If breakups cannot be used once a company has integrated, for some the best option would be inaction. There is little doubt that preventing anticompetitive mergers beforehand is better than prosecuting them afterwards. Moreover, the lowest-cost intervention-narrowly defined as the expenditures by government-will always be to do nothing and hope that markets will dislodge the monopoly, such as through disruptive innovation. ${ }^{342}$ Also, it is hard to argue with the proposition that, all else equal, antitrust should promote competition through the intervention with the least administrative costs.

However, it is difficult to identify all anticompetitive mergers in advance. ${ }^{343}$ Additionally, if the goal is to address monopoly power, we cannot be assured that an organic market disruption is around the corner. An extreme faith in markets to solve all problems has become far less common than it was during formative years in antitrust development. ${ }^{344}$ Since then, Nobel Prize-winning work in transaction costs, behavioral economics, and information asymmetries has laid the foundations for seeing that market failures are widespread and persistent. ${ }^{345}$

Moreover, the economic goal is not to lower the expenses incurred by the government and the monopoly in implementing the remedy. Instead, it is to advance competitive markets that improve consumer welfare-measured, in great part, by efficiency. ${ }^{346}$ To be sure, an efficiency analysis should include the

341 See K. Sabeel Rahman, The New Utilities: Private Power, Social Infrastructure, and the Revival of the Public Utility Concept, 39 CARDOZO L. REV. 162 1, 1670 (2018).

342 See Carstensen, supra note 119 , at 840 .

343 See Michael L. Katz \& Howard A. Shelanski, Merger Analysis and the Treatment of Uncertainty: Should We Expect Better?, 74 ANTITRUST L.J. 537, 538 (2007) (noting error risks).

344 See Shelanski \& Sidak, supra note 57, at 11-15 (citing the decline of Schumpeterian influence).

345 The recipients include Ronald Coase (1991) and Douglas North (1993) for transaction costs; George Akerlof, Michael Spence, and Joseph E. Stiglitz (2001) for information asymmetries; and Daniel Kahneman (2002) and Richard Thaler (2017) for behavioral economics. All Prizes in Economic Sciences, NOBEL PRIZE, https://www.nobelprize.org/prizes/uncategorized/all-prizes-in-economic-sclences/ [https://perma.cc/9SZ4-BQNT] (last visited Sept. 27, 2020).

346 See, e.g., Shelanskd \& Sidak, supra note 57, at 19 (discussing allocative efficiency). 
remedy implementation expenses. But there is no strong evidence that antitrust breakups harm efficiency. ${ }^{347}$ Therefore, the remedy that costs the least to implement-inaction-can be by far the most economically harmful choice if it leaves in place a monopolist that substantially lowers consumer welfare or provides incentives for anticompetitive mergers.

Defaulting to breakups would leave open the possibility of convincing evidence swaying the remedy choice in another direction, including towards inaction. If a startup is gaining rapid market share by using a game-changing technology, for instance, inaction may be preferable. Absent such compelling evidence to the contrary, however, there is strong support for defaulting to pursuing a breakup remedy when deciding between breakups and inaction.

In summary, the design of remedies should reflect antitrust law's institutional and political constraints. When the cost-benefit analysis yields a clear preferable remedy in any given case, that remedy should be adopted. However, in many cases economic analysis will fail to yield any firm conclusion as to the best remedy. In light of the existing constraints on antitrust agencies and trials, a purportedly neutral approach may produce outcomes counter to what antitrust most needs given the pressures toward under-deterrence. Furthermore, a working hypothesis that begins with breakups as the preferred remedy and resolves ambiguity in their favor would result in more actual breakups. This approach would thus produce the data points needed to reassess the hypothesis and readjust the legal framework in accordance with up-to-date, sophisticated empirics rather than outdated studies, historical anecdotes, and intuition. As a practical matter, a breakup default may be necessary to right the course toward eventually choosing breakups on the merits.

\section{Expanding Breakups}

Greater clarity about administering breakups speaks to perhaps the most controversial antitrust entity: the monopoly that did not obtain its dominance through mergers and has done nothing illegal. As a matter of law, "monopolists are permitted to keep their lawfully acquired market positions so long as they do not engage in exclusionary practices." ${ }^{348}$ Those firms can charge monopoly prices.

347 See supra Part II.

348 Hovenkamp, supra note 7, at 98-99. 
This Article does not establish that society would be better off by getting rid of the conduct requirement and prohibiting monopolies obtained by "superior skill, foresight and industry." 349 However, in two main ways a more comprehensive understanding of breakups weakens the existing antitrust allowance of such "successful" monopolies. First, the leading justification for allowing monopolies to exist and to charge monopolistic prices is to provide incentives for innovation and investment. ${ }^{350}$ Most famously, Justice Antonin Scalia explained:

The mere possession of monopoly power, and the concomitant charging of monopoly prices, is not only not unlawful; it is an important element of the free-market system. The opportunity to charge monopoly prices-at least for a short period-is what attracts "business acumen" in the first place; it induces risk taking that produces innovation and economic growth. To safeguard the incentive to innovate, the possession of monopoly power will not be found unlawful unless it is accompanied by an element of anticompetitive conduct. ${ }^{351}$

DOJ officials have echoed those concerns by citing the need "to protect the very incentives to innovate" as the leading, if not the only, obstacle to breakups. ${ }^{352}$ In particular, the articulated fear is discouraging entrepreneurs from starting up a company. ${ }^{353}$

In other words, innovation is the principal concern about breaking up firms that charge monopoly prices. Absent that concern, society would be better off ending the consumer welfare harms caused by monopoly pricing. This argument in favor of monopolies is powerful due to the consensus that innovation is a significant driver of economic growth and progressindeed, for many, innovation is the most important contributor

349 United States v. Aluminum Co. of Am., 148 F.2d 416, 430 (2d Cir. 1945). 350 See, e.g., David S. Evans \& Keith N. Hylton. The Lawful Acquisition and Exercise of Monopoly Power and Its Implications for the Objectives of Antitrust, 4 COMPETITION POL'Y INT'L 203 (2008) (“U.S. antitrust laws recognize . . monopoly profits as the desirable rewards for entrepreneurship.").

351 Verizon Commc'ns Inc. v. Law Offices of Curtis V. Trinko, 540 U.S. 398, 407 (2004) (emphasis in original).

352 Makan Delrahim, Assistant Attorney Gen., U.S. Dep't of Just., Remarks at the University of Haifa, "Start Me Up": Start-Up Nations, Innovation, and Antitrust Policy (Oct. 17, 2018), https://www.justice.gov/opa/speech/assistant-attorney-general-makan-delrahim-delivers-remarks-university-haifa-israel [https:/ /perma.cc/7MVJ-3R3Z].

353 See Joshua Wright \& Aurellen Portuese, Antitrust Populism: Towards a Taxonomy, 25 STAN. J.L. BUS. \& Fin. 131, 152 (2020). 
to growth. ${ }^{354}$ In arguing for structural remedies, scholars have often left the innovation incentives argument alone. ${ }^{355}$

Protecting innovation is valuable. However, in light of what breakups can accomplish as a remedy, innovation concerns do not support the current antitrust permissiveness of successdriven monopolies. To assess that concern, it bears emphasis that breaking up an organic monopoly would only happen when a company becomes extremely successful. That constraint means that the breakup could unfold in a way that would offer those who built the company sufficient rewards for their innovation.

To illustrate, consider how the innovation source of resistance to breakups would play out for Google, Facebook, and Amazon, which are currently leading targets for breakups. If Amazon were split into several companies-say its cloud computing business, its Amazon-owned sales business, and a platform-founder and CEO Jeff Bezos would still own stakes in enormous companies and still be among the wealthiest humans ever to exist, like Rockefeller was after the government carved up Standard Oil. ${ }^{356}$ It is hard to imagine future entrepreneurs would look to Bezos at that point and somehow be discouraged from following similar paths.

As further perspective, consider a hypothetical in which Amazon and Facebook were shut down by some antitrust administrative mistake without compensating their founders. In such a scenario, Bezos and Zuckerberg would still be extraordinarily wealthy, since not all of their wealth is tied up in their companies. It is not clear that, even under those circumstances, entrepreneurs would be discouraged from a path in which the worst-case antitrust scenario is extremely unlikely and would still leave them well-off and famous. Moreover, if such outcomes occurred by mistake, reforms could be implemented to change the breakup process. To be clear, this Article does not propose such a scenario, which would be risky from the perspective of innovation incentives and consumer welfare. Still, the hypothetical is informative because it shows the limited downsides as measured by the innovation argument's main concern.

354 See MiCHAEl A. CARRIER, INNOVATION FOR THE 21 st CENTURY 2 (2009); Howard A. Shelansk1, Information, Innovation, and Competition Policy for the Internet, 161 U. PA. L. REv. 1663, 1670-71 (2013).

355 See, e.g., Khan \& Vaheesan, supra note 24, at 287-91 (focusing on other goals).

356 See supra note 226 and accompanying text. 
Also, the sale of the company's assets can be assessed before completing the forced deal. If the proposed sale would leave the monopoly's founders and investors uncompensated to a degree that might discourage future innovation, the government could change course. That approach would address scholarly concerns about making investments in research and development unprofitable. The current policy of blanket prohibitions of breakups even when they would leave innovators amply compensated-a policy justified by concerns about those innovators-is inconsistent with the prevalence of profitable private divestitures that leave shareholders better off. ${ }^{357}$

Additionally, a defining feature of entrepreneurship is "high risk." 358 The vast majority of startups fail to yield significant returns on investment. ${ }^{359}$ If by error, antitrust enforcement happened to erase the wealth of an innovator who created a monopoly, it would be counterintuitive to assume such rare occurrences would discourage a group of people who are already undeterred by long odds. Of course, if breakups routinely wiped out the wealth of entrepreneurs, that would change incentives. Again, though, the historical record does not indicate that breakups impoverish entrepreneurs.

Despite the existing policy's questionable foundations, concerns about harming innovation should still inform the design of any no-fault monopolization standard. ${ }^{360}$ As mentioned above, when the remedy responds to a consummated merger or other illegal conduct, a breakup may need to be accompanied by disgorgement or penalties to sufficiently deter anticompetitive practices. However, when breakups are used against monopoly power obtained legally - by offering a better productsuch a penalty need not be part of the remedy. The goal would be to remove or lower the ability to exercise monopoly power. By allowing the entrepreneur in such situations to split up the successful monopoly and reap the rewards of the market price of that sale, antitrust law can address the harms from monopolies and the concerns about discouraging monopolies built on successful products.

\footnotetext{
357 See supra subpart III.A.

358 See D. Daniel Sokol, Antitrust's "Curse of Bigness" Problem, $118 \mathrm{MiCH}$. L. REV. 1259, 1275 (2020) (book review).

359 William R. Kerr, Ramana Nanda \& Matthew Rhodes-Kropf, Entrepreneurship as Experimentation, 28 J. ECON. PERSP. 25, 26 (2014).

360 On the importance of innovation informing antitrust remedies, see Keith $\mathrm{N}$. Hylton, A Unified Framework for Competition Policy and Innovation Policy, 22 TEX. INTELL. PROP. L.J. 163, 169-73 (2014).
} 
The innovation discussion in this subpart has so far focused on incentives to innovate up to the point of becoming a monopoly because that is the chief justification for the current antitrust regime. A related issue is worth considering briefly, albeit of secondary importance: What would be the effects on innovation moving forward of breaking up a monopoly? Antitrust scholars are divided on how such an intervention would affect innovation, ${ }^{361}$ but those debates omit the private sector's perspective on breakups. Many large firms have broken themselves up to become more innovative. ${ }^{362}$ There is reason to believe monopolies would be unlikely to pursue such innovation-improving divestitures if the effect would be to lessen their monopoly rents.

Thus, although it is beyond the scope here to settle the broader debate about innovation and antitrust, the most prominent normative foundation for allowing monopolies is in tension with the business sector view of breakups and innovation. It is inaccurate to state that we must tolerate monopoly prices because doing so is vital to motivating innovation. A more refined understanding of breakups shows that antitrust law can have it both ways by breaking up some currently lawful monopolies.

Moving beyond innovation, the rehabilitation of breakups informs debates about reforming antitrust law's treatment of successful monopolies. The law's permissiveness towards monopolies is easier to defend from a paradigm of unwieldy breakups. If breakups are viewed as disastrous or radical, there may be no viable remedy for a company that acquired and maintained its monopoly power legally. Behavioral remedies could work in some situations, but there would be no wrongful conduct to fix for an otherwise law-abiding firm.

Moreover, to preserve innovation incentives an organic monopoly would presumably need to be compensated by competitors for providing access. That would require the government to oversee the pricing of that access over time. Even more problematic would be situations in which access and traditional behavioral remedies do not fit. In those cases, the only remedy that would address monopoly prices may be price control or the government setting the price of the monopoly's products at something reflecting the competitive level. Yet price

361 For overvlews, see Woodcock, supra note 247, at 1415-21; Tim Wu, Taking Innovation Seriously: Antitrust Enforcement If Innovation Mattered Most, $7 \delta$ ANTITRUST L.J. 313, 314 (2012).

362 Supra subpart III.A. 
controls are economically disfavored. ${ }^{363}$ In other words, one of the potential obstacles to reforming antitrust law to prosecute more monopolies is the uncertainty how to intervene. An informed view of breakups provides a workable and promising remedy. There would need to be other reasons to want to allow the law to continue permitting monopolies, rather than due to the absence of a feasible remedy.

It merits emphasis that there is room for large businesses and some concentrated markets that bring more benefit to consumers and society than alternatives. Some companies, such as social networks, are limited in how far they can be broken up in the traditional sense without ruining what is valuable to consumers. ${ }^{364}$ The costs of a breakup, including any pro-competitive benefits of leaving the violator as a single company, must be considered when choosing a remedy. Also, courts should remain skeptical when it is not the government seeking the breakup, but a competitor suing its rival. A more expansive vision for breakups may be in order, but that does not mean that the government should go on a rampage to fragment all industries.

That said, the question of when a broken-up industry would improve consumer welfare is not the focus of this Article. Rather, the main point is that some of the key foundations for the current near-universal allowance of organic monopolies erode when viewed in the context of what is known about governance and divestitures outside of antitrust. There are other non-economic reasons some may oppose or support antitrust breakups of organic monopolies. ${ }^{365}$ But the leading economic foundations for allowing monopolies-providing motivation to innovate-are conjectural. Those foundations also sit in tension with widespread business practices, history, and a common-sense consideration of the example set by wealthy founders of broken up companies.

363 Joseph R. Mason, Robert Kulick \& Hal J. Singer, The Economic Impact of Eliminating Preemption of State Consumer Protection Laws, 12 U. PA. J. BUS. L. 781,795 (2010). An exception to the general view of price controls includes utilities. See William Boyd, Just Price, Public Uttlity, and the Long History of Economic Regulation in America, 35 YALE J. ON REG. 721, 750-51 (2018).

364 For a thoughtful challenge to no-fault monopolization, see Marina Lao, NoFault Digital Platform Monopolization, 61 WM. \& MARY L. REV. 755, 776-84 (2020).

365 Pro-monopoly arguments include autonomy and fears of government abuse of power, though similar arguments generally apply to antitrust law. Labor (employment) is also relevant. Arguments against monopolies include the consolidation of political power and inequality. 
In contrast, there are well-established consumer welfare harms caused by a firm charging monopoly prices. ${ }^{366}$ Thus, the main economic argument cited by Supreme Court justices, scholars, and antitrust authorities does not hold as the foundation for a universal rule that monopolies should not be broken up.

A more accurate understanding of administrability illuminates not only the flaws in the current regime, but also the path forward. It is possible to construct an antitrust policy that reflects both a valid emphasis on innovation and the economic value of limiting monopoly power. Legislative reforms could, for companies who obtained and maintained excess monopoly power lawfully, seek to break up those companies when possible to do so in a way that both preserves the core appeal to consumers and rewards the entrepreneurs for their innovation. Like in other areas of antitrust, judicial review would provide a check on abuse of such power.

Note that this proposal channels the leading scholarly justification of the status quo-innovation incentives-into designing a better approach to administering breakups. The framework is likewise consistent with Justice Scalia's emphasis on allowing monopoly profits "at least for a short period," since-unlike in the case of monopolies obtained or maintained by unlawful conduct-breaking up lawful monopolies would not involve disgorgement of those prior monopoly profits.

Without breakups, there will sometimes be nothing that antitrust can do to advance competition. Greater openness to breakups should be pursued because they address the clear harm of monopolies instead of emphasizing unproven risks of disastrous breakups or stifled innovation. Removing breakups' administrative misperceptions will recharge the law's power to combat monopolies and make the field less vulnerable to accusations of "irrelevance." 367 When breakups would benefit society, lawmakers and enforcers should not hesitate to use them-even in the face of monopolies previously thought untouchable.

\section{CONCLUSION}

Antitrust would benefit from a more interdisciplinary examination of breakups, drawing on both administrative law

\footnotetext{
366 See Lao, supra note 364, at 789-97 (reviewing the literature).

367 Harry First \& Spencer Weber Waller, Antitrust's Democracy Defict, 81 FORDHAM L. REV. 2543, 2543 (2013) (describing criticism of antitrust).
} 
scholarship and business scholarship. An outside-of-antitrust lens, along with a closer look at the existing case against breakups, reveals that the widespread, deeply ingrained antitrust hostility to breakups is unfounded. There is insufficient evidence that government-mandated breakups have harmed the economy. Moreover, business executives and shareholders regularly initiate breakups as part of good corporate governance. Owners overall emerge from those events wealthier than before, despite substantial costs, delays, and organizational upheaval. Antitrust authorities are being held to a standard of success that would cripple private sector mergers and acquisitions. Unless evidence emerges suggesting that such interventions are harmful, enforcers and courts should more liberally pursue breakups, and legislators should consider expanding the remedy's reach to currently legal monopolies.

Indeed, it is quite possible that even the breakup of incorrectly targeted companies could yield benefits to the economy and to the company. CEOs often pursue counterproductive empire building, thus producing more unmanageable companies that are unable to adapt with modern fast-changing markets. Many antitrust breakups would also yield non-antitrust efficiency and innovation gains currently omitted from the antitrust analysis. Although indiscriminate breakups would be counterproductive, these obscured gains show that the risks of incorrect identification are not as grave as characterized.

Most importantly, the potential upside for competition, and society, is substantial. Perhaps a better analogy for antitrust than unscrambling eggs is that controlled burns help reinvigorate forests, allowing ecosystems to regenerate and emerge more resilient than before. The working hypothesis moving forward should be that more breakups would have a similar effect on markets by incurring short-term costs in the service of preserving market health and competition in the long term. The only way to test that hypothesis is to begin exercising the authority that has long existed and that lawmakers and antitrust authorities have become irrationally reluctant to use. Doing so may not only end the mismanagement of the ultimate antitrust remedy, but also free the field from any enforcement paralysis. 
